\title{
California Customer Load Reductions during the Electricity Crisis: Did They Help To Keep the Lights On?
}

\author{
Principle Authors \\ Charles A. Goldman, Joseph H. Eto, and Galen L. Barbose \\ Energy Analysis Department \\ Environmental Energy Technologies Division \\ Ernest Orlando Lawrence Berkeley National Laboratory \\ University of California \\ Berkeley, CA 94720
}

http://eetd.lbl.gov/EA/EMS_pubs.html

May 2002

The work described in this study was funded by the Assistant Secretary of Energy Efficiency and Renewable Energy, Office of Power Technologies of the U.S. Department of Energy under Contract No. DE-AC03-76SF00098. 


\begin{abstract}
Recurring electricity shortages and rolling blackouts were widely forecasted for summer 2001 in California. Despite these predictions, blackouts were never ordered - in large part, due to the dramatic reductions in electricity use throughout the state. Compared to summer 2000, Californians reduced electricity usage by $6 \%$ and average monthly peak demand by $8 \%$. Our analysis suggests that these reductions were not caused by either the weather or the downturn in the state's economy; rather, they were the result of extraordinary efforts by Californians to reduce electricity consumption. Based on the California Independent System Operator's (CAISO) available operating reserve margin during summer 2001, we estimate that the peak load reductions, which ranged between 3,200 and 5,600 MW in the four summer months, potentially avoided between 50 and 160 hours of rolling blackouts.
\end{abstract}

This extraordinary response by Californians can be attributed to several factors including media coverage and informational campaigns that affected public awareness and understanding, real and/or perceived increases in electricity rates, and various policies and programs deployed by state policymakers and regulators to facilitate customer load reductions. Among these programs, we review the state's 20/20 rebate program, the utilities' energy efficiency programs, programs or initiatives implemented by the California Energy Commission and other state agencies, and load management and demand response programs offered by the state's investor-owned electric utilities and the CAISO.

We estimate that energy efficiency and onsite generation projects that were initiated in 2001 will account for about 1,100 MW of customer load reductions, once all projects are installed. These savings represent about $25-30 \%$ of the observed load reductions and are likely to persist for many years. The persistence of the remaining savings, which were due to changes that customers made in their conservation behavior and energy management operations, will be heavily influenced by customers' perception of continuing electricity crises or significant energy problems and price sensitivity to retail rate trends. The State's current demand response (DR) capability enrolled in utility or CAISO programs is somewhat lower than prior to the crisis. However, in the long run, enabling technologies for demand response deployed through the CEC's Demand Responsive Buildings and Real-time Metering programs have the potential to significantly increase demand response capability.

While unique factors led to the electricity crisis in California, we believe the lessons learned from electricity customers' response may be useful for other regions faced with the prospect of electricity shortages.

- During a short-term crisis, a comprehensive set of load reduction programs and policies can make a significant contribution towards maintaining electric system reliability and can be an effective alternative to strategies that rely solely on rationing demand (e.g. rolling blackouts) or dramatic price increases.

- Information from various media sources contributed to very high customer awareness of the electricity crisis and helped spur customers to take actions to reduce their electricity usage. Customers viewed the media as an important, and in many cases, trusted information source, 
which appears to have increased their receptivity to participating in various State and utility initiatives.

- A commitment to ratepayer-funded energy efficiency programs and energy efficiency standards for appliances and buildings are critical elements of a long-term strategy to dampen growth in electricity demand. California's energy efficiency services delivery infrastructure, which was strengthened by years of ratepayer and State-funded programs, represents a significant resource that was ramped up quickly to respond to a short-term energy emergency.

- It is important for regulators to adapt and re-design utility load management programs and retail tariffs long before an electricity crisis, so that retail customer loads can participate directly in bulk power markets and respond to high prices and/or system contingencies.

- If regions are facing chronic electricity shortages for hundreds of hours, then a 20/20-type program is worth considering. This type of program is most appropriate for residential and small commercial customers. Among large C/I customers, a combination of voluntary initiatives in government and private sectors, targeted financial incentives for high-efficiency or demand response equipment, and pricing/rate design strategies that reflect wholesale market costs are more likely to achieve load reductions at lower cost than a 20/20 type program. If electricity shortages are projected for only a few hours, then other types of demand-side initiatives may be more appropriate and effective (e.g., voluntary conservation, demand response or energy efficiency programs, pricing). 


\section{Acknowledgements}

Work reported here was coordinated by the Consortium for Electric Reliability Technology Solutions (CERTS) and funded by the Assistant Secretary of Energy Efficiency and Renewable Energy, Office of Power Technologies of the U.S. Department of Energy under Contract No. DE-AC03-76SF00098.

We would like to thank the following individuals for providing helpful comments on earlier drafts of the report: Larry Mansueti at U.S. Department of Energy, Marcy Beck, Chris Marnay, Jim McMahon, Mithra Moezzi, Jayant Sathaye, Robert Van Buskirk, and Steve Weil at Lawrence Berkeley National Laboratory (LBNL), Carl Blumstein at the UC Energy Institute, and Mike Jaske at the California Energy Commission (CEC).

We would also like to thank the following individuals for providing valuable information to support the analysis in this report: Dariush Arasteh, Emily Bartholomew, Chris Payne, and Robert Van Buskirk at LBNL, Loren Lutzenhiser at the University of Washington, Mike Messenger, Sanford Miller, and Melinda Merritt at the CEC, Tim Michel at Electric and Gas Industries Association, Ken Nittler at the California Window Initiative, Alan Fields at Regional Economic Research, Inc., Bill McNary and John Rivera at D\&R International, Mike Rufo at Xenergy, Wally McGuire at McGuire Co., Julia Curtis at Nexant, Andrew Bell, Chris Chouteau, Duane Larsen, Bill Miller, and Mike Wan at Pacific Gas and Electric Company, Don Arambula and Marian Brown at Southern California Edison, Athena Besa at San Diego Gas and Electric Company, and Julie Fitch and Tuukka Hess at the California Public Utilities Commission. 


\section{Table of Contents}

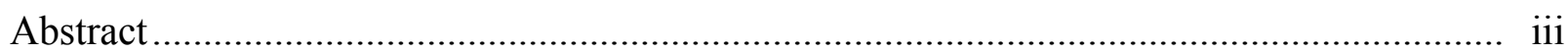

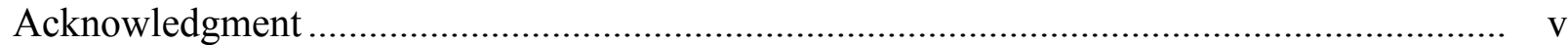

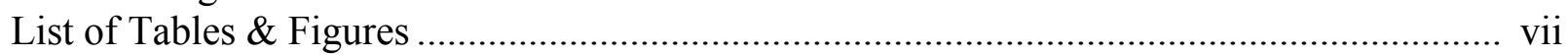

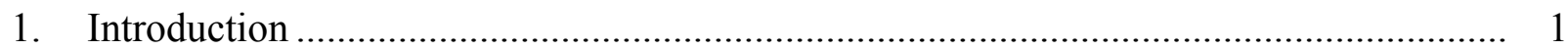

2. Californians Lowered Electricity Demand Significantly during the "Electricity Crisis ... 2

3. Customer Load Reductions Helped Keep the Lights on during Summer 2001 ............. 4

4. Heightened Public Awareness of the Electricity Crisis Played a Critical Role in Stimulating Customer Load Reductions .................................................................................... 6

5. Higher Electricity and Natural Gas Rates Underscored the Need to Reduce Loads........ 8

6. Traditional Load Management Programmatic Responses to Short-Term Electricity Shortages Contributed Little to Summer 2001 Load Reductions.................................. 10

7. The 20/20 Rebate Program was the State's Major Programmatic Initiative to Reduce Electricity Use

8. Utility Energy Efficiency Programs Exceeded Savings Goals by Relying Heavily on...... Energy Efficiency Services Infrastructure.....

9. Other State-led Efforts Contributed Savings That Will Extend Beyond Summer 2001 .... 17

10. Persistence and Sustainability of Customer Load Reductions................................... 19

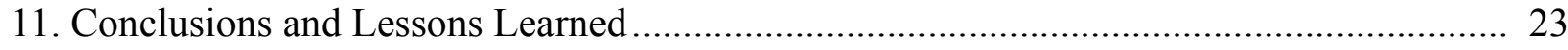

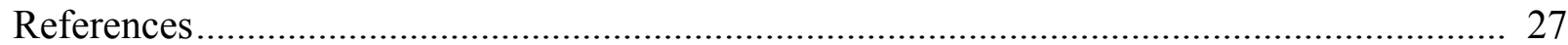




\section{List of Tables and Figures}

Table 1. CAISO System Emergencies Before and During the Crisis .................................... 5

Table 2. Telephone Survey Results: Most Important Issue Facing California Today?.......... 7

Table 3. Telephone Survey Results: Direct Impacts of Electricity Crisis on California Residents

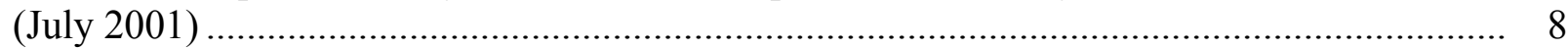

Table 4. Summary of California 2001 Demand Response Programs ..................................... 11

Table 5. Statewide Results of the 20/20 Rebate Program..................................................... 13

Table 6. Energy Efficiency, Onsite Generation, and Demand Response Technology Investments in 2001

Figure 1. Monthly Peak Demand (MW) and Electricity Sales (GWh) during 2000 and 2001 for the CAISO Control Region (CEC, 2001a) ........................................................................... 2

Figure 2. Comparison of California Temperatures in Summer 2002 and 2001.................... 3

Figure 3. Reductions in Monthly Peak Demand and Electricity Sales for the CAISO Control Region, Adjusted for Weather and Economic Growth (CEC, 2001a).................................... 4

Figure 4. Estimated Range of Hours of rolling Blackouts Potentially Avoided Through Customer Load Reductions During Summer Months......................................................... 6 Figure 5. Pacific Gas and Electric (PG\&E) Company's Electricity and Gas Prices (CPUC,

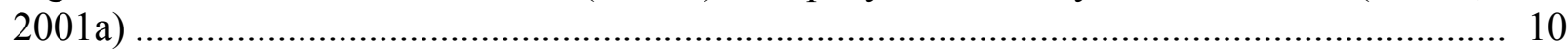

Figure 6. 2001 vs. 2000 Load Reduction Potential of Demand Response Programs .............. 12 


\section{Introduction}

In January 2001, the Governor of California, Gray Davis, declared a state of emergency, announcing that electricity supply shortages would continue, leading to rolling blackouts in the summer (Office of the Governor, 2001a). ${ }^{1}$ In April 2001, the North American Electric Reliability Council (NERC) predicted that California should expect 260-700 hours of rolling blackouts (NERC, 2001). Various sources predicted that electricity shortages would cause major disruptions to California's economy with estimates of economic damage ranging from $\$ 2$ billion to over \$20 billion (AUS Consultants, 2001; Bay Area Economic Forum, 2001). Yet, during summer 2001, rolling blackouts were never implemented. A major crisis, which some had predicted would likely cost the State many billion of dollars in economic losses, had been averted. This paper explores the contribution that the extraordinary reductions in electricity demand made in stemming the predicted barrage of rolling blackouts. While unique factors led to the electricity crisis in California (many of which are explored in other papers in this volume), we believe the lessons learned on how electricity consumption was reduced in summer 2001 have applicability for other regions faced with electricity shortages.

In Section 2, we assess the significance of weather and the economy (e.g., the "collapse of the internet economy") and review the analysis conducted by the California Energy Commission (CEC) on the observed reductions in electricity consumption and peak demand. Building on the finding that the reductions in electricity consumption are not attributable to weather or the economy, we turn, in the remainder of the study, to a review and analysis of the source of these reductions: customer actions (Goldman et al, 2002).

In Section 3, we analyze the reliability implications of customer load reductions (i.e., preventing rolling blackouts) by examining the added Operating Reserve Margin they provided during periods of high system electricity demands. Customer actions were the complex result of numerous interdependent factors and conditions: public awareness of the crisis, the perception of rising electricity prices, and a variety of policies deployed by regulators and policymakers, including a portfolio of programs to facilitate customer load reductions. We review these underlying factors in more detail in the next six sections:

- Public awareness and perceptions of crisis (Section 4)

- Electricity (and natural gas) price increases (Section 5)

- Traditional utility load management and demand response programs (Section 6)

- The 20/20 rebate program (Section 7)

- Traditional utility energy efficiency programs (Section 8)

- Other State-led programs (Section 9)

Our intent, however, is not to allocate or assign specific responsibility for the observed load reductions among these factors, for their effects are intertwined. In Section 10, we evaluate available information on a key planning issue emerging from all activities undertaken during

\footnotetext{
${ }^{1}$ Electricity cannot be stored inexpensively. So when supplies become tight, rolling blackouts are sometimes initiated in order to maintain reliability. Rolling blackouts are preventive measures taken by transmission grid operators to curtail provision of electricity to selected groups of customers. Customers typically have very little advance warning that they will be curtailed and the length of time they are curtailed depends on the severity of the electricity shortage.
} 
summer 2001: the likely persistence of these activities in lowering demand in future years. Our approach is to distinguish between customer investments in various types of equipment, which might be expected to continue providing load reductions into the future, and changes that customers made in their energy management operations or behavior, whose lastingness is less certain because it depends in part on their continuing perceptions of the severity of the electricity crisis. In the final section, we summarize key findings and lessons learned.

\section{Californians Lowered Electricity Demand Significantly during the "Electricity Crisis"}

Electricity consumers in the California Independent System Operator (CAISO) control region significantly reduced peak demand and electricity use in virtually every month of 2001, compared to 2000 (see Figure 1). ${ }^{2}$ Between January and May 2001, the monthly peak demand averaged $4.8 \%$ less and electricity consumption averaged $3.7 \%$ less than during the corresponding month of 2000. During the summer months (June-September), when demand for electricity is greatest, monthly peak demand decreased by an average of $8.4 \%$ and electricity consumption by an average of $6.1 \%$.

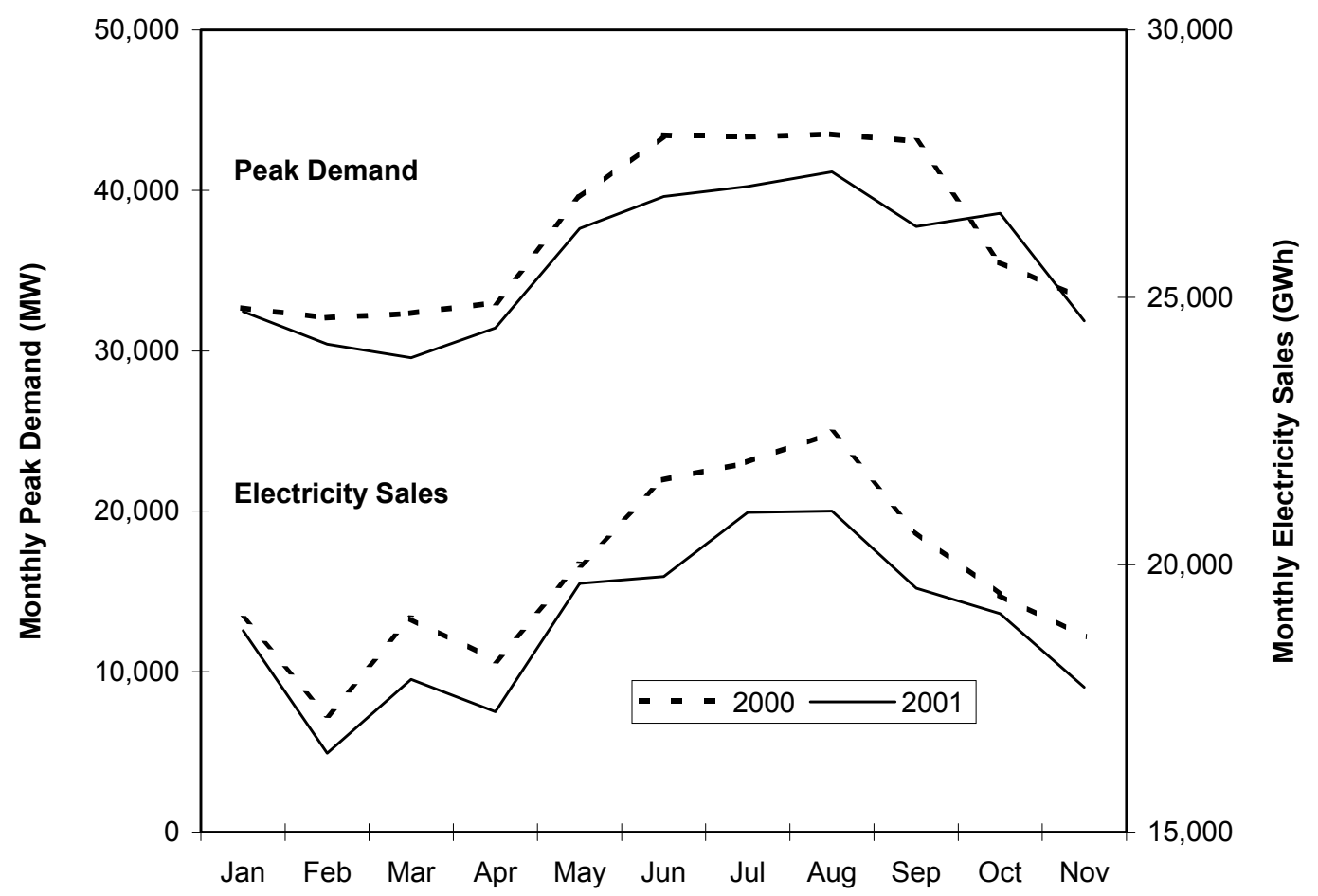

Figure 1: Monthly Peak Demand (MW) and Electricity Sales (GWh) during 2000 and 2001 for the CAISO Control Region (CEC, 2001a)

Many factors affect aggregate electricity demand, including weather, the economy, and in 2001, deliberate efforts by Californians to reduce their consumption. As a way to focus on the

\footnotetext{
${ }^{2}$ Loads in the CAISO control region account for $\sim 87 \%$ of statewide coincident peak load, and include the customers of the State's three investor-owned electric utilities (Pacific Gas and Electric, Southern California Edison, and San Diego Gas and Electric).
} 
influence of this final factor, it is useful to isolate and separately account for the influence of the first two factors. Isolating the influence of the weather and the economy is important because they were arguably not affected by the public's perception of an electricity crisis and the predictions of electricity shortages for the summer.

Some analysts have suggested that cooler-than-normal temperatures in 2001 were a major factor in lowering electricity use and peak demands in the summer (Chan, 2001). However, our analysis suggests that weather in summer 2001 was comparable to that of summer 2000 . We analyzed hourly temperature data from 122 weather stations throughout the State, aggregated by county, and weighted according to the population of the corresponding county. Plotted as a "temperature duration curve" (see Figure 2), the data show that summer temperatures in the State were almost indistinguishable between the two years. Moreover, the National Climatic Data Center has published data indicating that summer 2001 (June - August) was the $19^{\text {th }}$ hottest summer in the last 107 years (NCDC, 2002). Therefore, weather appears to have not been a driving factor behind the observed load reductions.

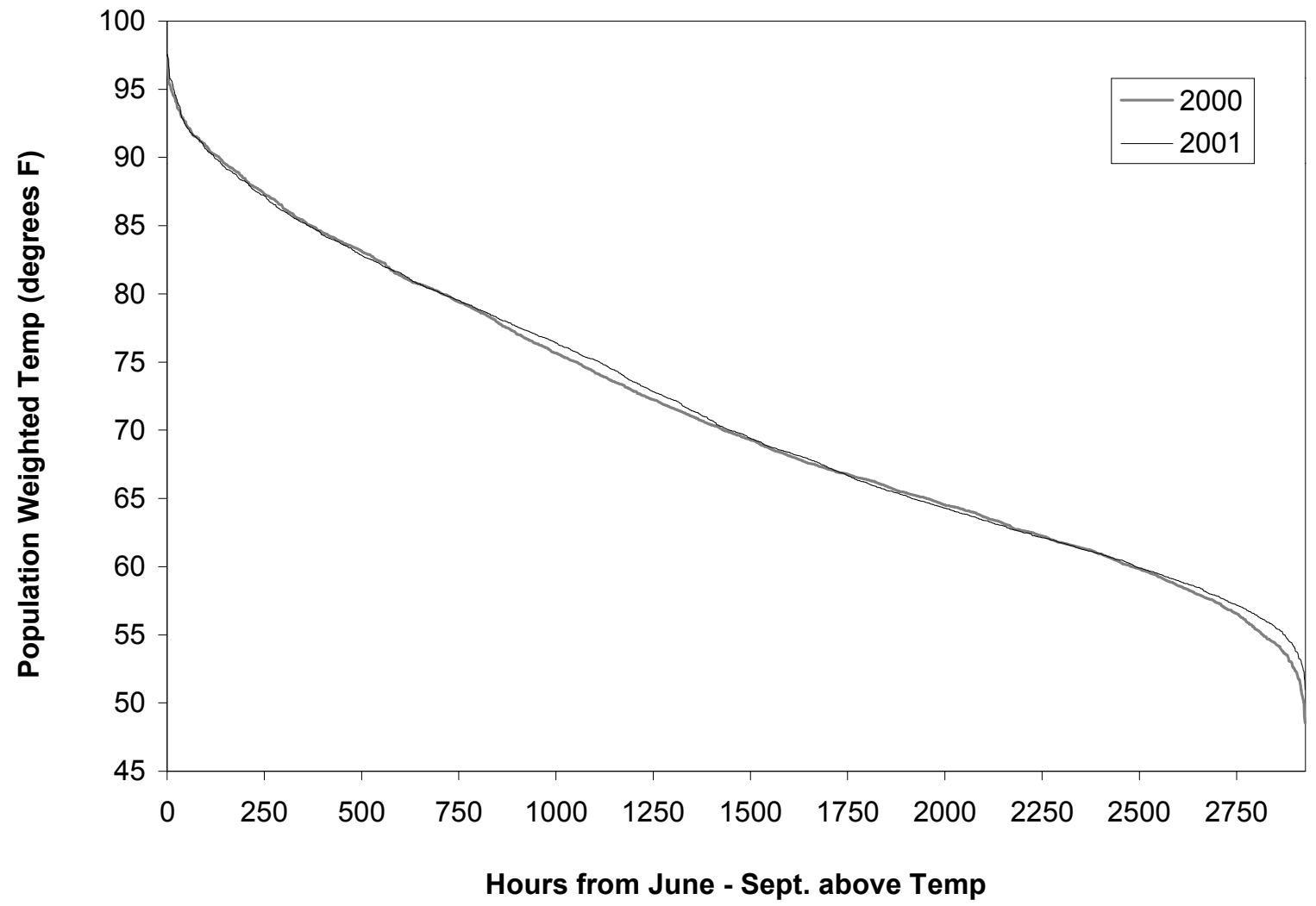

Figure 2: Comparison of California Temperatures in Summer 2000 and 2001

The downturn in the California economy - the collapse of the "internet economy" - has also been suggested to have had a major influence on depressing electricity use in 2001. While the relationship between electricity use and the economy is complex, this hypothesis is not supported by several economic indices. Gross state product grew by $2.3 \%$ in 2001 (OER, 2002), and average employment during the summer months increased by $0.8 \%$, compared to 2000 (DOF, 
2002). Thus, some small economic growth occurred between summer 2000 and summer 2001, and the effect of this growth - however modest - should have been to increase electricity use.

The California Energy Commission (CEC), the state agency charged with monitoring, assessing and forecasting California's electricity use trends, conducted an analysis that adjusts data for 2001 monthly electricity sales and peak demand to account for the effects of weather and economic growth (CEC, 2001a). The weather adjustments were developed by normalizing the monthly peak load and energy use data to typical temperatures for each month. Adjustments for economic/population growth were based on monthly employment data from the Employment Development Department. For almost all months, the data show that the reductions in peak demand and electricity sales adjusted for weather and economic factors are greater than that indicated by the unadjusted data (see Figure 3 ). The adjusted monthly peak demand reductions ranged from 2,000 - 5,600 MW throughout 2001. During the critical months of June through September, the adjusted peak demand reductions averaged $4,200 \mathrm{MW}$, equal to a $10 \%$ reduction in peak demand. Adjusted electricity sales $(\mathrm{GWh})$ decreased by $6,700 \mathrm{GWh}$, or $7.5 \%$ of expected usage, during the summer months, and by more than $16,400 \mathrm{GWh}$ over the entire year.

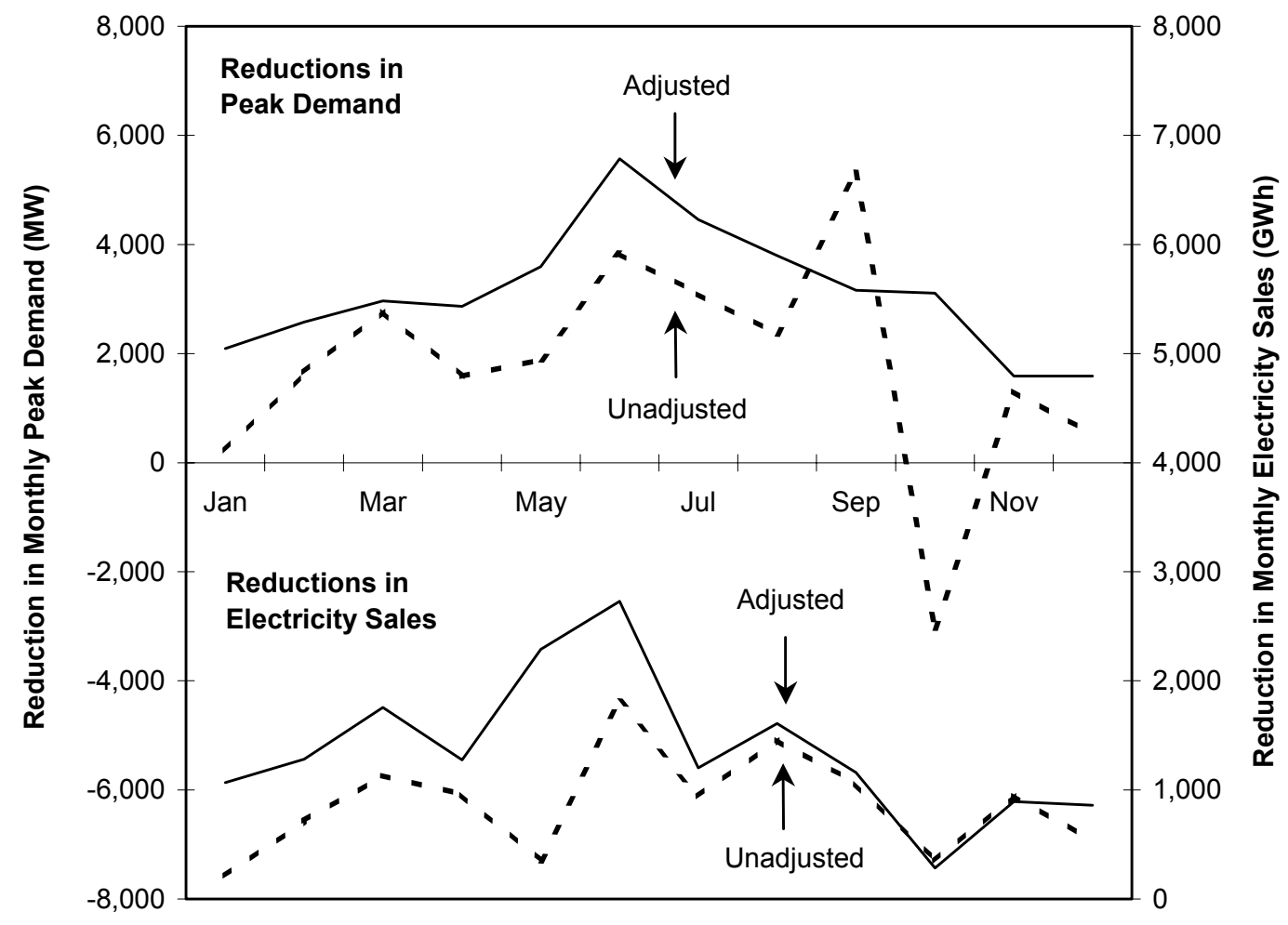

Figure 3: Reductions in Monthly Peak Demand and Electricity Sales for the CAISO Control Region, Adjusted for Weather and Economic Growth (CEC, 2001a)

\section{Customer Load Reductions Helped Keep the Lights on during Summer 2001}

Consumer actions to reduce their electricity consumption were the driving force behind the load reductions observed in summer 2001. In this section, we present a simple analysis, which estimates the added electricity system Operating Reserve Margin provided by customer load 
reductions during periods of high system loads. This analysis suggests that these actions were a significant reason the State was able to avoid rolling blackouts.

In order to ensure reliability, the CAISO constantly maintains generating operating reserves that stand ready to pick up loads immediately following the unexpected loss of large system elements, such as a key transmission line or a major generating station. Rolling blackouts are deliberate curtailments of electric service to customers called by system grid operators when available operating reserves are too low to maintain adequate safety margins and they are unable to obtain additional reserves. In these situations, system grid operators follow well-established procedures to curtail electricity service to pre-designated groups of customers in order to reduce load on the system and restore the proper safety margin. The philosophy underlying rolling blackouts is that it is better to deliberately curtail service to relatively few customers than to subject all customers to the risk that an unexpected loss of a key transmission line or generator will cause a cascading outage that curtails service to many more customers.

The CAISO issues Emergency notices when the reliability of the control region is threatened, including cases in which there is insufficient Operating Reserves Margin. A Stage 1 Emergency is called when reserves are projected to fall below a set of minimum criteria established by the Western Systems Coordinating Council. Stage 2 and Stage 3 Emergencies are subsequently called if reserves are projected to fall below 5\% and 1.5\%, respectively. Rolling blackouts are often required following declaration of a Stage 3. Prior to June 2000, Emergencies occurred infrequently, and statewide rolling blackouts had yet to be invoked since the CAISO's inception in 1998. However, beginning in summer 2000, the CAISO announced system emergencies, particularly Stage 2 and Stage 3 Emergencies, with increasing frequency (see Table 1). It was widely anticipated that the supply/demand balance would be extremely tight throughout summer 2001, and system emergencies would be a persistent problem. However, contrary to these predictions, the CAISO declared Stage 1 and Stage 2 Emergencies on only two occasions during summer 2001, and never ordered rolling blackouts.

Table 1: CAISO System Emergencies Before and During the Crisis

\begin{tabular}{|lccccc|}
\hline Number of Events & $\begin{array}{c}\text { "Pre-Crisis" } \\
\text { Dec 1998 - } \\
\text { June 2000 }\end{array}$ & $\begin{array}{c}\text { June - Sept. } \\
\mathbf{2 0 0 0}\end{array}$ & $\begin{array}{c}\text { Oct. 2000 - } \\
\text { Jan. 2001 }\end{array}$ & $\begin{array}{c}\text { Feb. - May } \\
\mathbf{2 0 0 1}\end{array}$ & $\begin{array}{c}\text { June - Sept. } \\
\mathbf{2 0 0 1}\end{array}$ \\
\hline Stage 1 & 12 & 31 & 56 & 45 & 2 \\
Stage 2 & 7 & 16 & 41 & 41 & 2 \\
Stage 3 & 0 & 0 & 19 & 20 & 0 \\
Rolling Blackouts & 0 & 0 & 4 & 4 & 0 \\
\hline
\end{tabular}

Source: CAISO, 2001a

To assess the reliability implications of customer load reductions, we combined information on customer load reductions with information from the CAISO on available generation capacity and aggregate demand. Based on this data, we calculated the available Operating Reserve Margin greater than $1.5 \%$ (i.e., the point at which rolling blackouts might be ordered) for every hour of summer 2001. Our analysis accounts for the 2,000+ MW of capacity added during the summer, net imports and exports of power, and generators' daily availability (planned and forced outages). 
In Figure 4, we rank the hourly available Operating Reserve Margin in excess of $1.5 \%$. In summer 2001, there were 50 hours in which there were less than $3200 \mathrm{MW}$ of operating reserves in excess of $1.5 \%$ of load. We then overlay the range of customer load reductions indicated by the CEC's adjusted monthly values for June - September (3,200 - 5,600 MW). These load reductions effectively provided an increase to the Operating Reserve Margin. As discussed previously, Stage 3 Emergencies are typically declared and rolling blackouts are often required when the Operating Reserve Margin falls below 1.5\%. Based on our analysis, customer load reductions maintained the Operating Reserve Margin above $1.5 \%$ for between 50 and 160 hours - thereby potentially avoiding Stage 3 Emergencies and the associated rolling blackouts.

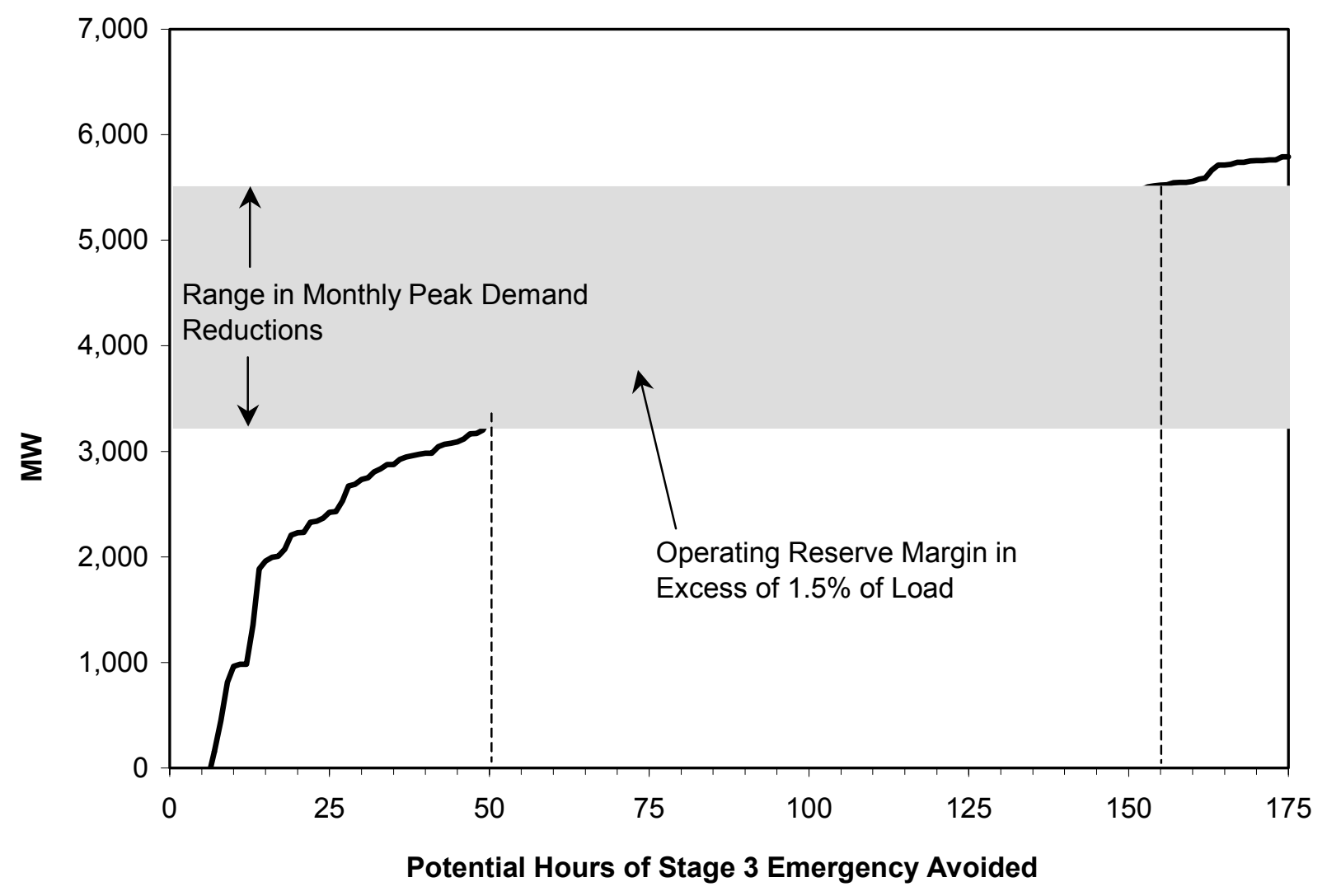

Figure 4: Estimated Range of Hours of Rolling Blackouts Potentially Avoided through Customer Load Reductions during Summer 2001

\section{Heightened Public Awareness of the Electricity Crisis Played a Critical Role in Stimulating Customer Load Reductions}

Significant increases in public awareness and perception of an electricity crisis (e.g., rolling blackouts, higher prices) played a critical role in stimulating customers to take actions to reduce loads before and during summer 2001. The extensive media coverage of electricity shortages and rolling blackouts during the year prior to summer 2001, as well as the price shocks experienced by customers in San Diego, convinced consumers in California that the electricity system was in a crisis and that dramatic actions were required on their part. We believe that the 
effectiveness of other utility and State programs and initiatives was significantly enhanced by this heightened degree of public awareness.

Public perception of electricity related issues - prices, cost, supply availability, and restructuring problems - changed significantly between 1998/1999, when it was not listed as an important issue by survey respondents, and summer 2001, when 56\% of residents mentioned electricityrelated issues as the most important issue facing California (see Table 2). Pollsters commented that it was the most dramatic change in the relative importance of the public's perception of policy issues in the last 20-30 years. During this period, the media initially provided extensive coverage of the price spikes that hit customers in San Diego in May 2000, after SDG\&E's rate freeze ended and the utility began to recover their actual (very high) wholesale electricity costs from customers in the following month. When wholesale prices rose dramatically, it led to consumer rate shock, then ensuing protests, severe hardships and closures for some small businesses, and ultimately a new cap on rates. These stories made front-page headlines throughout California and across the nation during summer 2000. Adding fuel to the fire, as the electricity supply/demand balance tightened, the CAISO called an unprecedented number of Emergencies (i.e., 22 Stage 2 Emergencies in 2000) and the first rolling blackout, which hit the Bay Area in June 2000.

Table 2: Telephone Survey Results: Most Important Issue Facing California Today?

\begin{tabular}{|l|cc|ccc|}
\hline \multirow{2}{*}{\multicolumn{1}{|c|}{ Issue }} & \multicolumn{2}{|c|}{ Pre-Crisis } & \multicolumn{3}{c|}{ Crisis } \\
\cline { 2 - 6 } & $\begin{array}{c}\text { Dec. } \\
\mathbf{1 9 9 8}\end{array}$ & $\begin{array}{c}\text { Dec. } \\
\mathbf{1 9 9 9}\end{array}$ & $\begin{array}{c}\text { Jan. } \\
\mathbf{2 0 0 1}\end{array}$ & $\begin{array}{c}\text { July } \\
\mathbf{2 0 0 1}\end{array}$ & $\begin{array}{c}\text { Dec. } \\
\mathbf{2 0 0 1}\end{array}$ \\
\hline $\begin{array}{l}\text { Electricity prices, cost, supply, } \\
\text { demand }\end{array}$ & $0 \%$ & $0 \%$ & $25 \%$ & $56 \%$ & $14 \%$ \\
Schools, education & $36 \%$ & $28 \%$ & $26 \%$ & $9 \%$ & $12 \%$ \\
Jobs, economy, unemployment & $5 \%$ & $5 \%$ & $4 \%$ & $5 \%$ & $15 \%$ \\
\hline
\end{tabular}

Source: Baldasarre, 1998, 1999, 2001a, 2001b, and 2001c.

Reporting by the media appears to have played a crucial role in educating and informing the public about California's emerging electricity crisis. For example, in January $2001,45 \%$ of respondents to the Public Policy Institute of California (PPIC) survey indicated that they were very closely following news stories about the cost, supply, and demand of electricity in California. The public's level of attention to electricity-related news stories was much higher than other stories that were widely covered during this time period (e.g., 13\% very closely following the governor and legislature, $38 \%$ very closely following President-elect Bush and plans of the new administration). By summer 2001, the PPIC survey reported that significant numbers of Californians were directly affected by the electricity crisis, either through higher prices or threat of rolling blackouts (see Table 3). Thus, in the case of electricity, the media's coverage of the "crisis" resonated with the actual experiences of many consumers. 
Table 3: Telephone Survey Results: Direct Impacts of Electricity Crisis on California Residents (July 2001)

\begin{tabular}{|lcc|}
\hline Impact & $\begin{array}{c}\text { Electric utility bills have increased for } \\
\text { many Californians. Problem for you? }\end{array}$ & $\begin{array}{l}\text { Some areas have had rolling blackouts or } \\
\text { threats of rolling blackout. Problem for you? }\end{array}$ \\
\hline Major Problem & $37 \%$ & $13 \%$ \\
Minor Problem & $40 \%$ & $31 \%$ \\
Not a Problem & $23 \%$ & $56 \%$ \\
\hline
\end{tabular}

Source: Baldasarre, 2001b

The media also provided extensive coverage of examples of what consumers could do to save electricity. Examples included human interest stories of residential customers that took extraordinary actions, such as getting off the grid by purchasing solar PV systems or virtually eliminating their electricity usage through dramatic changes in their energy-consuming behavior. Similarly, the media highlighted small businesses that reduced their electricity usage during peak periods in order to be "good corporate citizens." The media also provided advice from technical experts on reducing electricity usage as well as unsolicited suggestions and tips from end users. A survey of 400 California residential customers conducted after summer 2001 found that $62 \%$ and $75 \%$ of customers used newspapers and TV/radio respectively as sources of information on ways to save energy; and 22-25\% said that newspapers, TV, or radio were their most trusted information source (E Source, 2002). Lutzenhiser (2001) reported similar findings in a survey of 590 residential households in Southern California in which $44 \%$ of respondents indicated that news stories on television was a major source of influence on their conservation decisions and actions.

California's Department of Consumer Affairs also launched an aggressive media campaign, called Flex Your Power, in an effort to tap the conservation potential of the mass market. The media campaign created a network of TV, radio, newspaper, and billboard advertising and promotional material. The objective of the campaign was to raise public consciousness and awareness of the electricity crisis, provide educational information about conservation strategies, and provide information about financial incentives (e.g., the 20/20 rebate program). The focus of Flex Your Power was on encouraging conservation behavior (e.g., turning off lights, turning up the thermostat) rather than promoting energy efficiency investments.

\section{Higher Electricity and Natural Gas Rates Underscored the Need to Reduce Loads}

The effect of higher retail energy prices on lowering electricity demand was complex. Confusion over cost elements of monthly utility bills, consumer expectations of higher prices, and eventually large electricity price increases contributed to load reductions in summer 2001.

When California's electricity markets opened in 1998, retail electricity rates for customers of investor-owned utilities were frozen at or below 1996 tariff levels as mandated by the State's restructuring legislation, AB1890. Residential customers were on an inverted block rate for electricity usage $(\mathrm{kWh})$, so customers that consumed more paid higher rates. Large commercial 
and industrial customers ( $>500 \mathrm{~kW}$ peak demand) were required to have time-of-use meters and their rate included separate demand $(\mathrm{kW})$ and energy $(\mathrm{kWh})$ charges. ${ }^{3}$

As the electricity crisis deepened, PG\&E residential and small business customers did receive a "price shock" on their combined utility bill. However, it was caused initially by a significant increase in gas rates, driven by a large spike in gas commodity prices during Winter 2000/2001. Gas commodity prices typically vary on a monthly basis and gas distribution utilities pass through these price changes to residential and small business customers in the following billing cycle. Thus retail gas rates reflect changes in wholesale gas commodity prices relatively quickly in contrast to electricity rates. Figure 5 illustrates this phenomenon for PG\&E customers. Residential gas rates nearly doubled during Winter 2000/2001 (i.e. $\$ 0.85$ to $\$ 1.35-1.80 /$ therm), while electricity rates increased by $7-15 \%$ (depending on rate schedule) because of an emergency $1 \notin / \mathrm{kWh}$ increase in January 2001 (CPUC, 2001a). Some PG\&E customers, who receive both gas and electric service and hence a combined utility bill, did not distinguish between their gas and electricity charges and focused only on their total utility bill. Thus, the dramatic increase in utility bills during this period was often misdiagnosed (and was reacted to) as a rise solely in electricity costs.

Moreover, the extensive media coverage ensured that many consumers in the State were aware of the financial dimensions of the electricity crisis (e.g., PG\&E bankruptcy, retail rates that didn't recover high wholesale electricity prices) and the impact of rate-shocks that had hit SDG\&E customers during summer 2000. Thus, many consumers likely concluded that their electricity rates were likely to go up in the near future, which may have influenced their usage patterns or investment decisions.

In June 2001, the CPUC approved a 30\% increase in average electricity rates by customer (CPUC, 2001a). For residential customers, the CPUC adopted a rate design that created three new usage block tiers with higher rates. Large C/I customers faced significantly higher charges that were primarily allocated to the peak demand periods. The new rates sent a strong price signal for large commercial/industrial customers to reduce electricity consumption, particularly during the summer peak periods (e.g., 12-6 PM).

\footnotetext{
${ }^{3}$ The seasonal demand charge, which typically accounts for $20-30 \%$ of the total electric service bill for large customers, is billed at separate rates for each time of use period (e.g., on- and off-peak for summer and winter) and is skewed by more than a factor of two toward peak periods.
} 


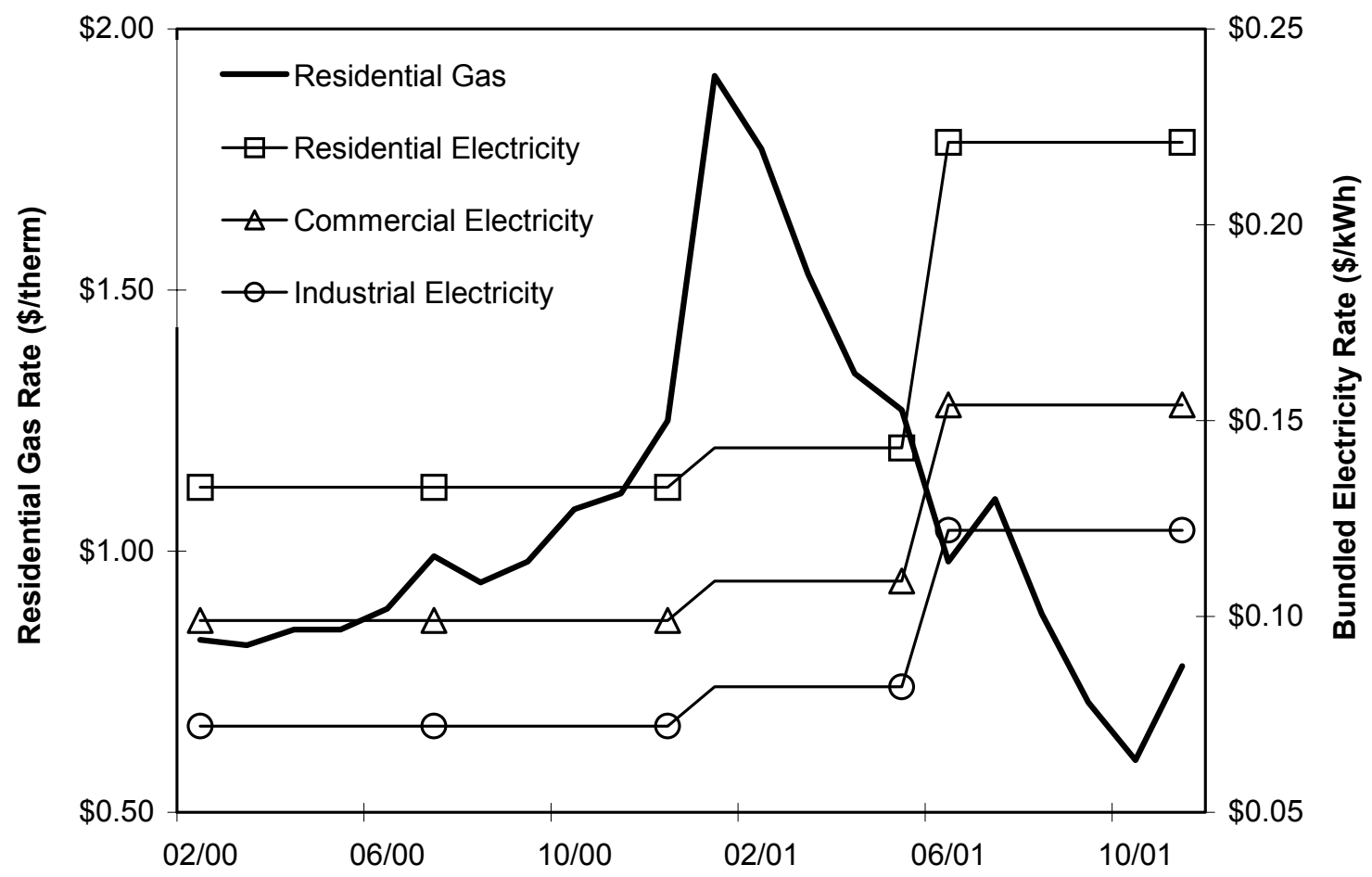

Figure 5: Pacific Gas and Electric (PG\&E) Company's Electricity and Gas Prices (CPUC, 2001a) ${ }^{4}$

\section{Traditional Load Management Programmatic Responses to Short-Term Electricity Shortages Contributed Little to Summer 2001 Load Reductions}

California utilities have offered interruptible rate and direct load control programs since the mid1980s. The programs successfully enrolled large numbers of customers, representing approximately $5 \%$ of system peak demand. In 2000, the interruptible rate and direct load control programs had load curtailment potential of $\sim 2,400 \mathrm{MW}$ and $300 \mathrm{MW}$ respectively. ${ }^{5}$ Prior to 2000 , the programs were seldom used and viewed as "insurance policy" as California had comfortable capacity reserves. During 2000, the utilities' load management programs provided significant reliability benefits and helped avert rotating outages on several occasions. However, as the crisis continued in 2001, the programs' effectiveness waned because the number of curtailments allowed under the program were exhausted and because many customers opted-out or refused to curtail when requested. New demand response programs offered by the utilities and CAISO were rarely utilized during summer 2001 because customer's successfully reduced their loads through conservation behavior, energy management, and energy efficiency investments.

With the onset of the electricity crisis in summer 2000, customers in load management programs were called upon to curtail with unprecedented frequency. Throughout the final eight months of

\footnotetext{
${ }^{4}$ Bundled electricity rates are based on typical usage patterns for that customer class.

${ }^{5}$ Customers electing to receive service on an interruptible rate schedule agreed to reduce their demand to a Firm Service Level (FSL) when called upon by the utility during system emergency conditions, for a limited number of hours per year (100-150 hours, depending on the utility). In exchange, these customers received significant rate discounts $(\sim 15 \%)$ on the demand charges for their "non-firm" load (i.e., the load above their FSL).
} 
2000, customers in the interruptible program were asked to curtail load on 23 occasions, and provided up to 2,200 MW of load reduction (CAISO, 2001a). During this period, the utility interruptible programs were instrumental in avoiding blackouts on at least five occasions. However, many interruptible customers were evidently not prepared to meet their obligations under the program. Customers representing 20\% of the load reduction potential in PG\&E's program and 55\% in SCE's program opted out by summer 2001, stripping the total potential load of the program down to approximately 1,200 MW (CPUC, 2001b; Wallenrod, 2001).

Furthermore, the program was used so frequently during January 2001 that the annual limit of 100 curtailment hours was exhausted for essentially all of the customers in PG\&E's program. As a result, only $800 \mathrm{MW}$ of potential load curtailment was available from the interruptible programs during summer 2001.

Due to the dramatic reduction in curtailable load from the interruptible programs and the anticipated threat of rolling blackouts in summer 2001, the CPUC and the CAISO scrambled to develop a set of new demand response (DR) programs for summer 2001 (see Table 4). The new DR programs embodied a wide range of program design concepts. Most of the programs were triggered by electrical system reliability conditions (e.g., Stage 2 Emergencies), although the Demand Bidding Program enabled customers to make load reduction bids on a day-ahead basis, with the objective of reducing the cost of electricity purchased on the spot market. The range and structure of incentive payments varied considerably (see Table 4).

Table 4: Summary of California 2001 Demand Response Programs

\begin{tabular}{|c|c|c|c|c|}
\hline Program Name & $\begin{array}{c}\text { Program } \\
\text { Administrator }^{\mathrm{a}}\end{array}$ & Description & $\begin{array}{c}\text { Operational } \\
\text { Trigger }\end{array}$ & Incentive Amount \\
\hline $\begin{array}{l}\text { Interruptible Rates and } \\
\text { Base Interruptible } \\
\text { Program }\end{array}$ & IOU & $\begin{array}{l}\text { Participants commit to } \\
\text { reduce to Firm Service Level } \\
\text { (FSL) upon notification. }\end{array}$ & Contingency & $\sim \$ 7000 / \mathrm{MW}-\mathrm{month}$ \\
\hline $\begin{array}{l}\text { Direct Load Control } \\
\text { (A/C Cycling and } \\
\text { Agricultural Pumping) }\end{array}$ & SCE & $\begin{array}{l}\text { Customer agrees to allow } \\
\text { utility to interrupt air } \\
\text { conditioning or agricultural } \\
\text { and pumping loads. }\end{array}$ & Contingency & $\begin{array}{c}\$ 0.014-0.40 / \text { ton- } \\
\text { day }\end{array}$ \\
\hline $\begin{array}{l}\text { Optional Binding } \\
\text { Mandatory Curtailment } \\
\text { (OBMC) }\end{array}$ & IOU & $\begin{array}{l}\text { Participants commit to curtail } \\
\text { at least } 15 \% \text { of the circuit } \\
\text { load during every rotating } \\
\text { outage. }\end{array}$ & Contingency & - \\
\hline $\begin{array}{l}\text { Demand Bidding } \\
\text { (DBP) }\end{array}$ & IOU & $\begin{array}{l}\text { Participants bid load } \\
\text { reductions day-ahead, } \\
\text { through DBP Web-site. }\end{array}$ & Market & $\$ 100-\$ 750 / M W h$ \\
\hline $\begin{array}{l}\text { Scheduled Load } \\
\text { Reduction (SLRP) }\end{array}$ & IOU & $\begin{array}{l}\text { Participants provide weekly } \\
\text { load reductions in four-hour } \\
\text { blocks on specific days. }\end{array}$ & Pre-scheduled & $\$ 100 / k W h$ \\
\hline $\begin{array}{l}\text { Rotating Blackout } \\
\text { Reduction Program } \\
\text { (RBRP) }\end{array}$ & SDG\&E & $\begin{array}{l}\text { Participants run Back-Up } \\
\text { Generators during all rolling } \\
\text { outages }\end{array}$ & Contingency & \$200/MWh \\
\hline $\begin{array}{l}\text { Demand Relief } \\
\text { Program (DRP) }\end{array}$ & CAISO & $\begin{array}{l}\text { Participants provide a pre- } \\
\text { specified load reduction upon } \\
\text { notification by CAISO. }\end{array}$ & Contingency & $\begin{array}{l}\$ 20,000 / \mathrm{MW}-\mathrm{month} \\
\text { and } \$ 500 / \mathrm{MWh}\end{array}$ \\
\hline $\begin{array}{l}\text { Discretionary Load } \\
\text { Curtailment Program } \\
\text { (DCLP) }\end{array}$ & CAISO & $\begin{array}{l}\text { Participants offer voluntary } \\
\text { load reductions in response } \\
\text { to requests by CAISO. }\end{array}$ & Contingency & $\$ 350 / \mathrm{MWh}$ \\
\hline
\end{tabular}

a. $\mathrm{IOU}=$ Investor-owned Utilities; CAISO = California Independent System Operator 
The CPUC's overall intent was to offer customers more flexible program designs in order to stimulate "demand responsiveness," mainly by offering participants more choice on whether or not to curtail (Jaske and Rosenfeld, 2001). However, in practice, many customers were confused by the number of choices and frustrated by the ongoing changes to program design that occurred during and prior to summer 2001 (Wallenrod, 2001). For example, the CPUC initially approved a demand bidding program for summer 2001, the Voluntary Demand Response Program, but later cancelled this program and replaced it with the Demand Bidding Program, which didn't become operational until July. As a result of confusion among customers, some utility DR programs fell short of their participation goals. The CAISO was initially quite successful in signing up load aggregators into its Demand Relief Program. However, participation was affected by the CAISO's ongoing financial difficulties and inability to guarantee prompt payment, which resulted in significant attrition.

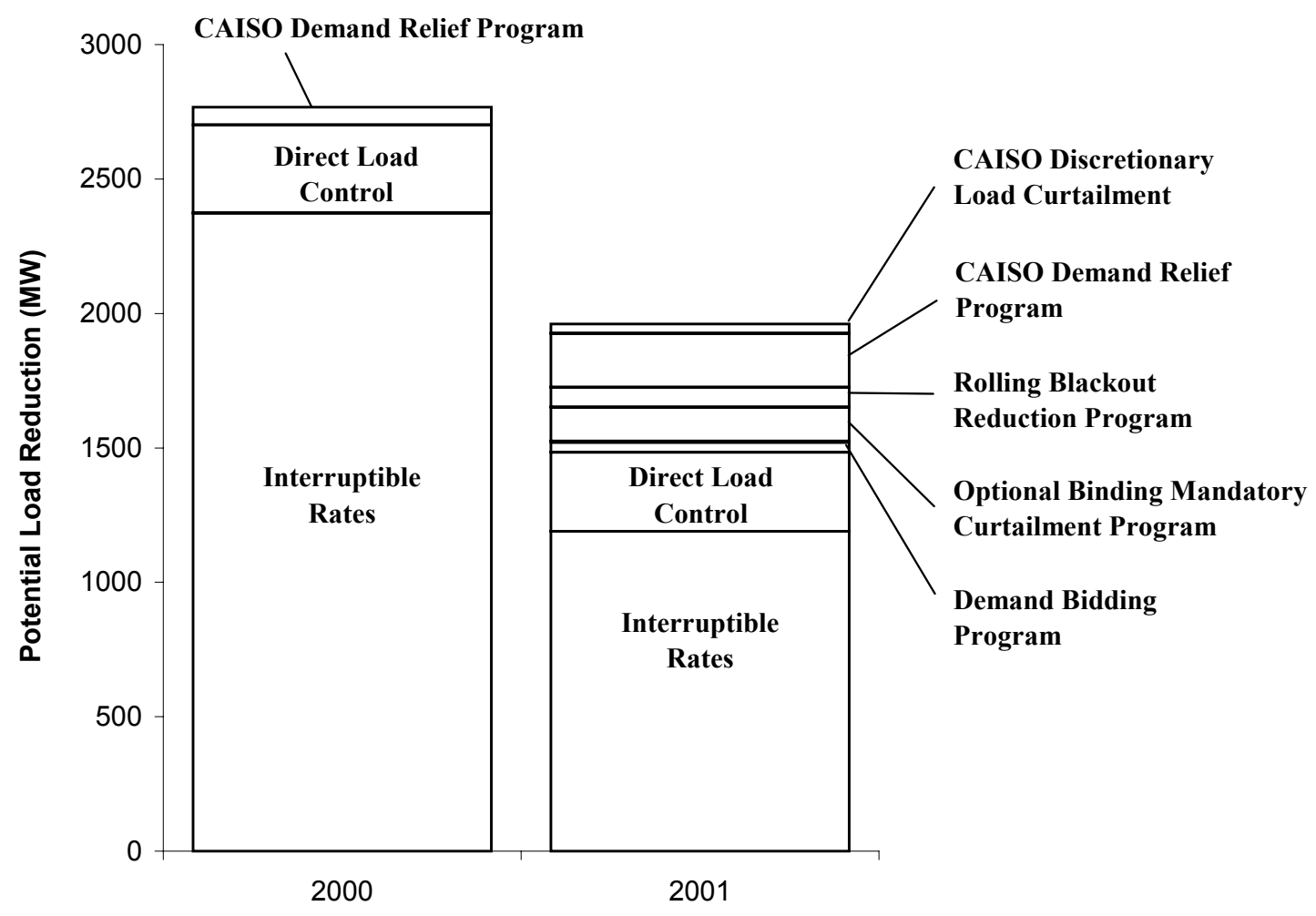

Figure 6: 2001 vs. 2000 Load Reduction Potential of Demand Response Programs

Once the utility and CAISO DR programs were off the ground, a total of approximately 1,900 MW of load reduction potential was enrolled, about $850 \mathrm{MW}$ less than was potentially available during 2000 (see Figure 6). Ironically, the various DR programs were rarely, if ever, utilized. The interruptible and direct load control programs, along with the CAISO's DR programs, were operated only once during the summer (on July 3), providing a total of approximately $800 \mathrm{MW}$ of load relief. This was due in large part to the success of customer load reductions associated with the variety of programmatic and non-programmatic forces discussed elsewhere in this paper. 


\section{The 20/20 Rebate Program was the State's Major Programmatic Initiative to Reduce Electricity Use}

One of the most heavily publicized, and at times controversial, programmatic activities to stimulate load reductions was the State-directed 20/20 rebate program. Our examination of this program highlights the tension among a variety of competing program design and implementation policies, including the desire for program simplicity, concerns regarding fairness, and the effectiveness of the program in reducing peak demands. By estimating a range for the ultimate cost of the program, we also illustrate the difficulty of assigning unambiguous responsibility to any single programmatic or regulatory initiative in reducing customers' loads in summer 2001.

Initiated by Executive Order of Governor Davis, the 20/20 program provided rebates to customers of the investor-owned utilities that reduced their monthly summer electricity usage (i.e., June - September) by some minimum amount compared to 2000 usage levels in that month (Office of the Governor 2001b). The rationale for the 20/20 program was that, for qualifying customers, the rebates would dampen the effect of increased rates, and the program might lower the overall cost of electricity by reducing spot market volumes and prices.

The program was unique both in its simplicity and in the fact that participation was automatic and available to all customer classes. Residential and small commercial/industrial customers received a $20 \%$ rebate off the electricity commodity portion of their bill if they reduced their total monthly electricity use by at least $20 \%$ compared to the same month in the previous year. Large commercial/industrial customers with time-of-use meters received a $20 \%$ rebate off their summer on-peak (weekdays, 12 - 6 PM) demand and energy charges if they reduced their onpeak electricity use by $20 \%$ or more. Customers of SDG\&E were only required to reduce their usage by $15 \%$, because the CPUC had lifted the freeze on their the electricity rates in July 1999 and it was assumed that they had already reduced their electricity usage in summer 2000 in response to their rising electricity rates.

Table 5: Statewide Results of the 20/20 Rebate Program

\begin{tabular}{|lccc|}
\hline Customer Class & $\begin{array}{c}\text { \% Of Customers } \\
\text { Receiving Credit }\end{array}$ & $\begin{array}{c}\text { Electricity Reduction } \\
\text { (GWh) }\end{array}$ & $\begin{array}{c}\text { Total Rebate Amount } \\
\text { (\$M) }\end{array}$ \\
\hline Residential & $33 \%$ & 3,021 & $\$ 134$ \\
Non-Residential & $26 \%$ & 2,237 & $\$ 153$ \\
\hline Total & $32 \%$ & 5,258 & $\$ 286$ \\
\hline
\end{tabular}

Based on the overall number of customers receiving rebates, the program was highly successful (see Table 5). ${ }^{6}$ About $32 \%$ of all customers received rebates in one or more of the four months of program operation. The three investor-owned electric utilities (IOUs) reported that they provided $\$ 286$ million in rebates on customers' bills through the 20/20 program for about 5,300 GWh of reduced electricity consumption. ${ }^{7}$ Including utility administration expenses and other

\footnotetext{
${ }^{6}$ Data obtained from private correspondence with utility personnel. Electricity reduction from PG\&E estimated, based on reported rebate amount.

${ }^{7}$ The utilities were reimbursed for these rebates by DWR, which was purchasing power on behalf of the utilities because of their credit problems or insolvency.
} 
costs, total expenditures for the $20 / 20$ program were estimated at about $\$ 350$ million (DWR, 2001a).

Examining the effectiveness of the 20/20 program is complicated by many factors:

1. Some customers received $20 / 20$ rebates, yet due to inherent fluctuations in their baseline energy use, may have actually done little to qualify. Accounting for this effect reduces the "savings" that should be attributed to the program.

2. Some customers did not qualify for $20 / 20$ rebate in a particular month, although they reduced their electricity usage and undertook significant actions in an effort to qualify. Accounting for this effect increases the "savings" that should be attributed to the program.

3. Customers could qualify for rebates from both the 20/20 program and any one of a number of other state- or utility-led programs. Accounting for this effect decreases the savings attributable to the program.

4. For residential and other smaller customers, reductions in monthly electricity use, which were the basis for qualifying for the rebate, may not have been accompanied by reductions in peak period electricity use, which was a key rationale for offering the program. Accounting for this effect does not change the savings attributable to the program but lowers the value of these savings.

We have attempted to account for first three of these factors to illustrate how they affect the ultimate cost of electricity saved by the program.

Consumer's electricity use naturally fluctuates from year to year. In any two consecutive years, some fraction of customers will reduce their electricity use by at least $20 \%$ in one or more months, simply due to these normal variations in usage (e.g., due to vacations, change in schedule or occupancy), rather than from deliberate conservation efforts. From the perspective of evaluating the cost effectiveness of the program, the monthly reductions in electricity use associated with these customers must be deducted from the 5,300 GWh of paid electricity savings. According to an analysis conducted by PG\&E, approximately $21 \%$ of all residential customers would be expected to reduce their electricity use by $20 \%$ or more during at least one month from June through September due to normal year-to-year variations in usage under similar weather conditions (Bell, 2001). Lutzenhiser (2001) analyzed utility billing data for June 2000 and 2001 for 590 households in Southern California and found that $16 \%$ of households increased their usage by $20 \%$ or more. By extrapolating this effect to all residential customers in the State, and assuming the effect was half as large for non-residential customers, we estimated that approximately $2,000 \mathrm{GWh}$, or $38 \%$, of the electricity savings paid for by the $20 / 20$ program was unrelated to conservation efforts.

Many customers who did not receive a rebate from the program during a particular month may nevertheless have been motivated by the program to use less than they would have otherwise. From the perspective of evaluating the cost effectiveness of the program, the conservation associated with their actions must be included in the electricity savings attributed to the program. Ordinarily, customers who do not reduce their usage by at least $20 \%$ in particular months would, in aggregate, consume about $2,000 \mathrm{GWh}$ more than in the previous summer. ${ }^{8}$ However, this

\footnotetext{
${ }^{8}$ Over the entire customer population, we assume that aggregate electricity use would be comparable in consecutive years with similar weather and ignore the effects of economic growth/activity on electricity use.
} 
group of customers consumed only about $300 \mathrm{GWh}$ more, based on the total reduction in electricity sales in the CAISO control region for summer 2001. Thus, these customers, in effect, reduced their consumption by $1,700 \mathrm{GWh}$ from what it otherwise would have been; some portion of this reduced usage can be attributed to the $20 / 20$ program. We estimate that at least $30 \%$ of the $1,700 \mathrm{GWh}$ reduction in electricity sales (i.e., $500 \mathrm{GWh}$ ) may possibly be attributable to the $20 / 20$ program, based on surveys of customer awareness of the $20 / 20$ program. ${ }^{9}$

Taken together, we estimate that customers with about $3,800 \mathrm{GWh}$ of load reductions $(3,300$ GWh from customers who qualified for the program plus $500 \mathrm{GWh}$ from non-qualifying customers) may have been influenced to some degree by the 20/20 program. Based on a 20/20 program cost of $\$ 350 \mathrm{M}$, the lower bound for the cost of purchasing savings through the 20/20 program was approximately $\$ 90 / \mathrm{MWh}$ if we assume that these load reductions are solely attributable to the 20/20 program. ${ }^{10}$ For comparison purposes, the average prices for contracted energy purchased by the California Department of Water Resources (DWR) during January-May 2001 was $\sim \$ 260 /$ MWh while spot market purchases averaged $\sim \$ 281 /$ MWh (DWR 2001). ${ }^{11}$

We regard the $\$ 90 / \mathrm{MWh}$ estimated cost of purchasing energy savings as a lower bound because of the synergistic effects from other state and utility programs, regulatory actions, and public awareness/media campaign. For example, many customers undoubtedly became aware of the 20/20 program through public media campaigns and/or might have reduced their usage in response to higher rates. Moreover, customers that received financial incentives for purchasing high-efficiency appliances, lights or equipment could also qualify for rebates on their monthly utility bills if they qualified under the $20 / 20$ program provisions.

Accounting for these synergistic effects is a complicated and data-intensive analytical exercise that is beyond the scope of this paper. It is straightforward, however, to calculate how accounting for these influences might increase the cost of saved electricity. For example, if only about $1,300 \mathrm{GWh}$ of savings could be attributed to the 20/20 program, or one-third of our initial estimate of $3,800 \mathrm{GWh}$, the estimated cost of electricity savings in the $20 / 20$ program would be in the $\$ 260-280 / \mathrm{MWh}$ range, which is comparable in cost to power purchased by DWR.

\section{Utility Energy Efficiency Programs Exceeded Savings Goals by Relying Heavily on Energy Efficiency Services Infrastructure}

Utility energy efficiency programs are the traditional programmatic companions to the load management activities described in Section 6. However, unlike their load management

\footnotetext{
${ }^{9}$ A survey of 400 residential customers in California conducted by E Source in October 2001 found that about $70 \%$ of residential customers took active steps to reduce their electricity consumption during Summer 2001. Of these customers, only $57 \%$ were aware of the $20 / 20$ program - thus, at most $40 \%$ of all residential consumers could have been motivated by the program to reduce their consumption.

${ }^{10}$ However, our "savings" estimates do not credit the 20/20 program for savings that may persist beyond the 2001 summer period. If some customers purchased high-efficiency equipment or lights solely in response to the 20/20 program, then these equipment-related savings will likely persist over the economic lifetime of that equipment, reducing the cost of saved energy of the 20/20 program.

${ }^{11}$ We chose supply option prices for the January-May 2001 period because this was the time frame when the 20/20 program was designed and the State was assessing the merits of demand-side strategies compared to supply purchase options.
} 
counterparts, significant regulatory efforts in California to maintain and enhance these programs in direct response to restructuring enabled them to play a major role in reducing customer loads in summer 2001. Looking forward, the actions stimulated by utility and other State energy efficiency programs account for a significant portion of the load reductions that can be expected to last and help prevent shortages in future years.

California investor-owned utilities (PG\&E, SCE, SDG\&E, and SoCal Gas) have administered relatively large energy efficiency programs since the late 1970s, with funding levels of \$200-400 million per year. Current programs are available to all classes of customers and provide a range of opportunities, including financial incentives (e.g., rebates), technical and design assistance, energy audits, information, and training. For the most part, the programs focus on stimulating customer behavior, operations, and, especially, investments that lower overall energy use. Many programs, such as those that target air conditioning, also have significant impacts on utility peak demands because they lower energy use during period of high electricity demand, such as hot summer afternoons.

In 1998, California's restructuring legislation halted the decline in utility energy efficiency funding that occurred in the mid-1990s and guaranteed funding for four years through the creation of a public benefits charge of 1-2 mills per kWh collected from each customer (CPUC, 2001c). As part of an envisioned transition to a competitive retail electricity market, the CPUC articulated new policy principles to better align future energy efficiency programs with the emerging competitive electricity market (Eto et al, 1998). Chief among these new policies was increased reliance on the energy service company (ESCO) industry to provide energy efficiency services to customers and expansion of program delivery approaches in ways that explicitly considered the supply chain for energy efficiency products and services.

The utilities explicitly targeted many of their 2001 energy efficiency programs to provide immediate electricity savings and peak demand reductions, which involved increased funding for and redesign of some programs. The CPUC authorized the investor-owned utilities to spend approximately $\$ 320$ million of public goods charge funds on energy efficiency programs during 2001 and established a peak demand savings goal of $\sim 250 \mathrm{MW}$. The utilities also received about $\$ 105$ million of incremental funding from general tax revenues for energy efficiency programs as part of "emergency" legislation (SB 5X) passed by the State Legislature.

Because of their longevity and relative size, the utilities' programs have raised awareness and understanding of energy efficiency technologies and strategies among customers and have facilitated the creation of an energy efficiency services infrastructure within the State. This existing infrastructure of contractors, ESCOs, vendors, and retailers was a critical factor in California's ability to ramp up and successfully implement a broad array of energy efficiency initiatives on a "crash" schedule.

The investor-owned utilities significantly exceeded their demand reduction and savings goals. By September 2001, customers participating in the utility energy efficiency programs installed energy efficiency measures that reduced summer peak demand by about $320 \mathrm{MW}{ }^{12}$ Moreover, the utilities also signed contracts with contractors, builders, ESCOs and customers for energy

\footnotetext{
${ }^{12}$ Source: Utilities’ 2001 Energy Efficiency Programs Quarterly Reports to CPUC.
} 
efficiency projects that will ultimately lead to another $140 \mathrm{MW}$ of demand reduction when installed. ${ }^{13}$ These programs are expected to be a major contributor to the savings initiated in summer 2001 that can be counted on to persist and help prevent shortages in future years (see Section 10).

Many programs were exceptionally well received, as evident by the unprecedented level of customer response and vendor/retailer participation. Estimated market share for compact fluorescent light bulbs (CFLs) increased from $0.6 \%$ to $8.5 \%$ during 2001 with 8 million new CFLs installed, driven mainly by rebates (Pang, 2001). SCE reported a four-fold increase in rebates paid to residential customers during 2001 (i.e., 200,000 vs. 50,000 in 2000), totaling almost \$20 million (SCE, 2001a). PG\&E provided \$13 million in rebates for purchase of highefficiency refrigerators, a five-fold increase compared to 2000 (PG\&E, 2002a). A number of large retailers that target mass markets (e.g., Sears, Home Depot, Costco) adopted various strategies ranging from exclusive selling of high-efficiency (e.g., Energy Star) products to customized assistance/advice on energy efficiency to small businesses. "Energy efficiency" acquired newfound marketing power among retailers, who consciously promoted "energy efficient" products and leveraged consumer interest created by the statewide media campaigns.

\section{Other State-led Efforts Contributed Savings That Will Extend Beyond Summer 2001}

Many other state-led efforts contributed to summer 2001 savings, although, in some areas, the full effects of these efforts will be realized over the longer term. California state agencies mobilized significant resources in support of myriad near- and longer-term initiatives to reduce electricity demand. State-led initiatives that focused on producing near-term peak demand reductions included mandated or voluntary load reductions by state, local and federal governmental agencies, voluntary partnerships with private sector businesses, and programs that provided funding to state agencies and/or financial incentives to end users or contractors for peak demand reductions. State agencies, especially the California Energy Commission, also undertook initiatives designed to reduce electricity demand over the longer term, which included financial incentives to install distributed energy resources, energy efficiency standards for appliances and buildings, and widespread deployment of real-time metering and two-way communications infrastructure.

Reduction in energy consumed in State government facilities (7\% overall and 20\% during electricity emergencies) was one of the first demand side initiatives proposed by Governor Davis in response to the crisis. During several Stage 3 Emergencies in 2001, the California Department of Water Resources curtailed $300 \mathrm{MW}$ of pumping loads (CAISO, 2001a). Overall energy use in State office buildings decreased by $23 \%$ during the first six months of 2001 (Office of the Governor, 2001c). ${ }^{14}$ Efforts at State agencies were augmented by commitments from Federal agencies to reduce energy use by $7 \%$, as well as partnerships with local government. Ultimately, over 225 cities, counties, and special districts across the State made voluntary pledges, including San Francisco, Oakland, and San Jose, each of which committed to reducing energy use by $15 \%$ at municipal facilities (Office of the Governor, 2001d).

\footnotetext{
${ }^{13}$ Most of these "committed" projects will be completed during 2002/03 and involved new construction and replacement of expensive HVAC equipment in large $\mathrm{C} / \mathrm{I}$ facilities.

${ }^{14}$ These savings estimates were not adjusted for weather effects.
} 
The State also facilitated many voluntary partnerships with private sector businesses and trade associations. More than one hundred CEOs signed declarations to reduce consumption by $20 \%$, through implementing specific conservation measures. These state initiatives were directed at raising the level of "corporate energy consciousness" and were unique in that top-level senior management was targeted, rather than the typical practice of focusing on mid-level facility or energy managers. Voluntary partnerships were also formed with agricultural customers, who shifted irrigation pumping loads from the summer peak and saved an estimated several hundred megawatts.

The State Legislature also passed various legislation (AB970, SB5X, AB29X) that authorized $\sim 860$ million in general taxpayer funds for various State agency programs designed primarily to reduce peak demand and, secondarily, to mitigate the impacts of the electricity crisis on lowincome consumers. The CEC administered about $40 \%$ of these funds for programs mandated by the Legislature, which included demand responsive building systems $(\$ 35 \mathrm{M})$, low-energy usage building materials $(\$ 35 \mathrm{M})$, innovative efficiency and renewables projects $(\$ 50 \mathrm{M})$, agricultural energy efficiency $(\$ 70 \mathrm{M})$, loans to schools and local government $(\$ 50 \mathrm{M})$, LED traffic signals, time of use and real time meters $(\$ 35 \mathrm{M})$, and renewables projects $(\$ 35 \mathrm{M})$. We estimate that these programs achieved about $335 \mathrm{MW}$ of verified peak demand reductions as of September 2001 , of which $\sim 60 \%$ was obtained by the Demand Responsive Building System program element. In this program, the CEC provided incentives to third parties (e.g., utilities, retail service providers, contractors) to install demand response technologies that enable commercial, industrial, and institutional customers to respond in near real-time to price signals or electric system contingencies. The CEC Demand Responsive Building System program was designed to facilitate customer participation in either the CAISO or utility demand response programs (see Sect. 5), although there were very limited opportunities to evaluate program impacts under actual field conditions, because there were few system emergencies during summer 2001.

Various state agencies also initiated peak demand reduction initiatives that are likely to achieve results over the long term. For example, in response to state legislation, the CPUC and CEC established programs that provided significant financial incentives for customers to install "clean" distributed generation equipment (e.g., micro-turbines, fuel cells, wind turbines, photovoltaics, and internal combustion engines) that must be inter-connected for parallel operation with the utility grid. ${ }^{15}$ During 2001, the peak demand savings impacts of these programs was relatively small ( $\sim 25 \mathrm{MW}$ ). Reasons include the following: (1) the CEC/CPUC incentive programs for self-generation were relatively new, (2) the relatively long period of time required to develop and install these type of projects, and (3) the cost premium for "clean" onsite generation technologies compared to diesel-fired units, which still dominate the back-up, emergency generation market.

AB970 also directed the CEC to update and revise its minimum efficiency standards for appliances and new buildings that result in maximum feasible reductions in uneconomic,

\footnotetext{
${ }^{15}$ Incentive levels vary by technology and cover up to $30-50 \%$ of project costs. Distributed generation that is installed on the end-user side of the meter can be used: (1) as an alternative to taking electric service from the distribution utility; (2) to provide end-users with primary power, with the utility supplying backup power; (3) for emergency backup power only, with the utility providing most or all of the end-user's electrical needs; or (4) to provide the end user with primary power and to sell the excess (ORA, 2002).
} 
inefficient consumption of electricity as part of a balanced response to the State's electricity problems (Public Resources Code 25552(b)). Twenty different types of appliances are included in the CEC's proposed regulations, including 19 appliances that are not regulated by federal laws and two appliances with more stringent standards than currently required by Federal law. The CEC's proposed appliance standards are estimated to save $125 \mathrm{MW}$ each year (CEC, 2002a).

Finally, in AB29X, the State appropriated \$35 million to the CEC to install real-time meters and communications links for all commercial/industrial customers with a demand of $200 \mathrm{~kW}$ or greater, which represented $\sim 30 \%$ of the investor-owned utilities (IOUs) peak demand (CEC, 2001b). This program was designed to address the fact that California end users are, for the most part, shielded from the hourly price fluctuations in wholesale electricity markets. There are many variants of real time pricing; most involve day-ahead posting of hourly electricity prices and installation of interval meters so that hourly customer demands can be charged separate rates (Borenstein 2001; Jaske and Rosenfeld, 2001). The CEC established contracts with each of the State's IOUs and several large municipal utilities to fund $\sim 22,000$ meters, at a cost of approximately $\$ 1500 /$ meter. As of September 2001, approximately one thousand meters were installed, but the CPUC did not authorize tariff changes that would allow the IOU's to implement real time pricing programs. Thus, the real-time metering program did not have much impact in summer 2001, although this activity has significant potential to influence future electricity demands.

\section{Persistence and Sustainability of Customer Load Reductions}

Customers reduced their electricity loads during summer 2001 through conservation behavior, increased attention to managing energy use, and investments in high efficiency equipment, appliances, onsite generation, and demand-response technologies. It is important to assess the extent to which these load reductions are likely to persist and be sustained over time, given their important contribution to balancing generating resources and loads in the California market.

The persistence of customer load reductions depends primarily on their source. For example, investments in high-efficiency equipment are likely to reduce energy consumption and peak demand over the economic lifetime of the equipment, producing savings that are likely to be sustained over time. Investments made by customers to improve demand response capability such as automated energy management control systems, load controllers, and interval meters with two-way communications enhance the ability of customer loads to be price-responsive for many years. The long-term impacts on system loads from customer investments in onsite generation depend mainly on the customer's operational strategy for that equipment (e.g., emergency generation with only infrequent operation vs. primary resource to serve onsite loads with many hours of operation). Changes in customer behavior and energy management/operation also reduce electricity usage and peak demand, but it is much less clear that these savings will persist over time.

We collected and analyzed information on customer investments in energy-efficient equipment, appliances, buildings, on-site generation, and demand-response enabling technologies in order to address the likelihood and magnitude of sustainable customer load reductions. Sources included energy-efficiency program results reported by electric utilities, the CPUC, CEC, and other State 
agencies (CEC, 2002b), third-party evaluations of State-funded programs (Nexant, 2001), demand response program results, customer market research on conservation actions during 2001 (E Source, 2002; Quantum Consulting, 2001), and data on permits for emergency, back-up generation $(\mathrm{CEC}, 2001 \mathrm{c})$. We also interviewed consultants, utility program managers, and trade associations to obtain information on aggregate energy-efficiency market activity in California.

We analyzed customer load reductions in the following categories: (1) utility and State-funded energy efficiency programs, (2) other energy-efficiency market activity (i.e., customer purchase of energy-efficient products and services that were not directly incented through a utility or State program), (3) onsite generation programs that provided financial incentives for installation of "clean" equipment (e.g., gas engines, turbines, photovoltaics), and (4) programs that provided incentives for customers to install demand-response (DR) enabling technologies or participate in DR programs. Table 6 shows estimated customer load reductions that are attributable to energy efficiency, onsite generation, or demand response technology investments during two time periods: (1) projects completed by the end of summer 2001 and (2) all projects that are expected to be completed based on signed contracts with program administrators. ${ }^{16}$

Our analysis suggests that about $420 \mathrm{MW}$ of customer load reductions during summer 2001 can be directly attributed to investments in energy efficiency or onsite generation projects. Over the long term, when all energy efficiency and onsite generation projects are installed, we believe that about 1060-1100 MW of customer load reductions are very likely to continue over their economic lifetime. It is important to note that our estimates of load reductions from energy efficiency market activity (i.e. 83-126 MW) are more uncertain and likely to under-estimate savings because market data is not available for certain high-efficiency equipment, appliances, or technologies. In summary, once committed projects are completed, we estimate that about 25$30 \%$ of the $4,200 \mathrm{MW}$ of customer load reductions observed in summer 2001 will be attributable to savings from energy efficiency or onsite generation projects and are likely to persist for many years.

Assessing the impacts of the California electricity crisis on customer's demand response (DR) capability is more complex and must reflect both a short- and long-term perspective. Recall that demand response/load response programs have traditionally been regarded as an "insurance policy" to be used by grid operators only rarely during system emergencies. Customer participation in the existing commercial/industrial interruptible rate program plummeted after 2000 , where statewide customer enrollment dropped from $\sim 2,400 \mathrm{MW}$ to $\sim 1,200 \mathrm{MW}$. Some of these customers migrated to new demand response programs offered by the CAISO and utilities. However, in aggregate, demand response capability represented by customers enrolled in utility and CAISO programs in 2001 was about 850 MW lower compared to 2000 (see Figure 6). These new DR programs were not utilized in 2001, so customer response and performance is untested. Since summer 2001, the CAISO has cancelled its Demand Relief Program and Discretionary Load Curtailment Program, and the demand response capability of the utility programs has dropped by more than $200 \mathrm{MW}$. Thus, in the short-term, the state's current DR capability is probably somewhat lower and less dependable than prior to the crisis. However,

\footnotetext{
${ }^{16}$ It is important to account for projects that will ultimately be completed based on customer contractual commitments because of the time lags involved in developing and implementing energy efficiency or onsite generation projects at customer facilities.
} 
over the long term, the CEC's Demand Response Buildings and Real-time Metering programs have the potential to significantly increase DR capability. Approximately 20,000 large commercial/industrial customers with peak demand greater than $200 \mathrm{~kW}$ will have installed realtime meters with two-way communications capability by 2003 . Real-time metering provides a much broader platform in the future for either dynamic pricing or demand response programs. ${ }^{17}$ Similarly, customer concerns regarding electric system reliability led to significant increases in their purchases of emergency, back-up generation equipment (e.g., $\sim 80 \%$ increase in total capacity between 1999 and 2000), which is a key technology to enable demand response. ${ }^{18}$

Our analysis of energy efficiency and onsite generation investments suggests that most of the customer load reductions during summer 2001 were attributable to conservation behavior and energy management actions. Customers undertook these actions for various reasons: the desire to be good citizens, to help the State out of a perceived crisis, concerns about high electricity bills, and/or the desire to obtain the $20 \%$ rebate from the 20/20 program (Lutzenhiser, 2001). It took a major crisis to stimulate these widespread changes in end user's conservation behavior and energy management actions. It is unclear to what extent these changes will persist over the long-term. Almost $80 \%$ of 590 residential customers surveyed in SCE's service territory during September/October 2001 indicated that they were likely to continue their conservation actions in the future assuming the energy situation stayed the same (Lutzenhiser, 2001). Given the terms and conditions of long-term power contracts negotiated by DWR and the financial fall-out from the 2001 crisis, it appears that retail customers will probably face high rates for an extended period of time. Thus, more price-sensitive customers are likely to continue conservation behavior and energy management practices implemented during the crisis for some period of time. Moreover, even though tight market conditions have eased in California, the financial and political "fall-out" from the crisis is still prominent in media coverage, while related events (e.g., crisis in Mideast, vulnerability of oil supplies, and jumps in gas prices) tend to make customers more conscious of their energy consumption. Thus, some fraction of those customers that are primarily motivated by "good citizen" or "environmental" concerns are likely to continue their "conservation ethic" behavior as their contribution to mitigating California's electricity market woes or other national energy/environmental issues. Other, less price-sensitive customers will probably return to pre-crisis usage patterns, particularly if the State's economy rebounds, which will cause some portion of the load reductions from conservation behavior and energy management to erode over time.

\footnotetext{
${ }^{17}$ The extent to which real time meters and other demand response enabling technologies installed through the CEC's programs will contribute to a demand response capability in the future depends on, among other factors, actions by state regulators. To date, the CPUC has not approved a real time pricing tariff.

${ }^{18}$ Data on back-up generator permits is only available through April 2001, so it is not possible to estimate emergency generator market activity for 2001. Anecdotal evidence (e.g., trade press, discussions with utility program managers) suggests that it was at least comparable to or greater than 2000 market activity.
} 
Table 6: Energy Efficiency, Onsite Generation, and Demand Response Technology Investments in 2001

\begin{tabular}{|c|c|c|}
\hline & $\begin{array}{c}\text { Estimated Load } \\
\text { Reductions from } \\
\text { Projects Installed as } \\
\text { of 10/1/01 (MW) } \\
\end{array}$ & $\begin{array}{c}\text { Projected Load } \\
\text { Reductions } \\
\text { from all } \\
\text { Projects (MW) } \\
\end{array}$ \\
\hline \multicolumn{3}{|l|}{ Energy Efficiency Programs } \\
\hline $\begin{array}{l}\text { Public Good Charge (PGC) Programs - Investor-owned } \\
\text { Utilities (IOU) }\end{array}$ & $319^{\mathrm{a}}$ & $457^{\mathrm{b}}$ \\
\hline State-funded Programs (SB5x) - CPUC/IOU & $8^{\mathrm{c}}$ & $152^{\mathrm{c}}$ \\
\hline State-funded Programs (AB970, SB5x, AB29x)-CEC & $42^{\mathrm{d}}$ & $228^{\mathrm{e}}$ \\
\hline $\begin{array}{l}\text { State-funded Programs (SB5x, AB29x) - Other State } \\
\text { Agencies }\end{array}$ & $5^{\mathrm{f}}$ & $43^{\mathrm{f}}$ \\
\hline Other Energy Efficiency Market Activity & NA & $83-126^{\mathrm{g}}$ \\
\hline Energy Efficiency Total & 374 & 963-1,006 \\
\hline \multicolumn{3}{|l|}{ Onsite Generation } \\
\hline Self Generation Program - CPUC & $20^{\mathrm{h}}$ & $71^{\mathrm{h}}$ \\
\hline Renewables Buydown Program- CEC & $4^{\mathrm{i}}$ & $15^{\mathrm{i}}$ \\
\hline State-funded Programs (AB970, SB5x, AB29x) - CEC & $14^{\mathrm{d}}$ & $16^{\mathrm{e}}$ \\
\hline Onsite Generation Total & 38 & 102 \\
\hline \multicolumn{3}{|l|}{ Demand Response Capability } \\
\hline Existing Interruptible and Direct Load Control & $1,476^{j}$ & $1,331^{j}$ \\
\hline New IOU \& CAISO DR Programs & $459^{\mathrm{j}}$ & $165^{\mathrm{j}}$ \\
\hline State-funded Programs (AB970/29x/SB5x) - CEC & $275^{\mathrm{d}}(70)$ & $376^{\mathrm{e}}(70)$ \\
\hline Emergency, Backup Generators & $370^{\mathrm{k}}$ & $443^{\mathrm{k}}$ \\
\hline Real-time Meters - CEC (AB29x/SB5x) & $\mathrm{NA}^{1}$ & $\mathrm{NA}^{1}$ \\
\hline Incremental Demand Response Capability & $899^{\mathrm{m}}$ & $678^{\mathrm{m}}$ \\
\hline
\end{tabular}

a) Source: (PG\&E, 2001c; SCE, 2001c; SDG\&E, 2001b). Tables 6.2, 6.4, and 8.2. Actual peak demand reductions as of Oct. 2001 are estimated based on interviews with utility managers of Statewide programs (158 MW). For non-statewide programs, $50 \%$ of the reported $83 \mathrm{MW}$ were assumed to have been installed by Oct. 2001. Summer Initiative Program results report actual (119 MW) and committed peak demand reduction.

b) Source: (PG\&E, 2002a; SCE, 2002a). Tables 6.2 and 8.2.

c) Source: (CPUC, 2001d). Peak demand reductions do not include impacts for low-income weatherization program, which represented about $20 \%$ of total incremental funding under SB5X for utility programs.

d) Source: (Nexant, 2001). For each program offered by the CEC, Nexant verified peak demand reductions for projects if possible. Projects in each program element were grouped into following categories: energy efficiency (42 MW), load shifting (5.5 MW), onsite generation (13.8 MW), demand response (264.9 MW).

e) Source: (Nexant, 2001). Projected peak demand savings for each applicable program element was estimated based on projects currently under contract. Measured realization rates from installed projects were used to adjust these estimates when possible.

f) Source: (CEC, 2002b). The California Conservation Corps reported $40 \mathrm{MW}$ of non-coincident peak demand reductions through distribution of 1.8 million CFLs. We modified this estimate to be $5 \mathrm{MW}$ of coincident peak demand reductions. Additional savings of $38 \mathrm{MW}$ is attributed to State Energy projects funded by SB 5X, which is assumed to be completed after 10/1/01.

g) Sources: Residential market activity for high-efficiency windows, refrigerators, clothes washers, dishwashers and room A/C estimated at $26 \mathrm{MW}$ (McNary, 2002; Nittler, 2002). Certain residential technologies, such as insulation, central $\mathrm{A} / \mathrm{C}$, programmable thermostats, and whole house fans are not included in this analysis because market share data is not collected or available. Small and medium C/I market activity was estimated at $40 \mathrm{MW}$, which was predominantly lighting measures. Savings were extrapolated from customer market survey data (Quantum Consulting, 2001), with energy and peak demand savings for customer facilities (i.e. 10 $\mathrm{MWh} / \mathrm{year}$ and $2.2 \mathrm{~kW} /$ customer) drawn from utility program evaluation results for similar customers (Rufo, 
2002). Large C/I market activity was estimated to range between 17-60 MW, based on 10-35\% of estimated peak demand savings achieved during 2001 by participants in utility and State agency programs $(\sim 170 \mathrm{MW})$.

h) Source: (CPUC, 2002). About $43 \mathrm{MW}$ of load reductions reserved incentives by Dec. 2001; assume that $\sim 50 \%$ of projects installed by 10/01 ( $20 \mathrm{MW})$. About $71 \mathrm{MW}$ of load reduction from all projects that had filed application, which was used to estimate projected load reductions.

i) Source: (Miller, 2002).

j) Source: Based on monthly reports to CPUC, by utilities, on interruptible and rotating outage programs, and on CAISO 2001 Operations Economic Report (PG\&E, 2001d; SCE, 2001d; SDG\&E, 2002a; PG\&E, 2002b; SCE, 2002b; SDG\&E, 2002; CAISO, 2001b).

k) Source: (CEC, 2002c; OPT, 2001). The CEC database on back-up generator (BUG) permits is current to April 2001 and only includes BUGs with capacity greater than $300 \mathrm{~kW}$. We assumed that BUG installed capacity in 2001 was comparable to 2000. For BUG with installed capacity less than $300 \mathrm{~kW}$, we scaled up the CEC total BUG capacity for 2000 based on the ratio of installed capacity of BUGs below and above $300 \mathrm{~kW}$, as reported in OPT (2001).

1) NA - Not directly applicable or not available

m) Totals for Incremental Demand Response Capability include enrollment in new IOU and CAISO DR programs, estimated number of participants from contractors in CEC DR programs that are not also enrolled in utility or ISO programs (shown in parentheses), and the capacity of back-up generation installed in 2001.

\section{Conclusions and Lessons Learned}

In this section, we summarize major conclusions and lessons learned from our analysis of load reduction initiatives during the California electricity crisis.

- During summer 2001, Californians made extraordinary efforts to reduce their electricity usage and average monthly peak demand (by $6.1 \%$ and $8.4 \%$ respectively compared to summer 2000). Weather in summer 2001 was very similar to summer 2000 and both years were hotter than normal. Data for both Gross State Product and Employment indicate modest economic growth between summer 2000 and summer 2001. Thus, the observed load reductions between the two summers were not primarily due to changes in weather or the economy. After making adjustments for temperature and economic growth, the CEC estimated that Californians reduced electricity usage by $7.5 \%$ and average monthly peak demand by $10.4 \%$ during summer 2001 (see Section 2).

- Customer load reductions were a significant reason that the State was able to avert the barrage of rolling blackouts predicted for summer 2001. Based on an analysis of the available Operating Reserve Margins, we conclude that between 50 and 160 hours of Stage 3 Emergencies and rolling blackouts were potentially avoided during Summer 2001 as a result of customer load reductions (see Section 3).

- Information from various media sources contributed to very high customer awareness of the electricity crisis and helped spur customers to take actions to reduce their electricity usage. Customers viewed the media as an important, and in many cases, trusted information source, which appears to have increased their receptivity to participating in various State and utility initiatives (e.g., 20/20 and utility energy efficiency programs) [see Section 4].

- During 2001, retail electricity rates increases seen by nearly all customers served by California investor-owned utilities lagged behind and were less severe than wholesale electricity price changes. State regulators targeted rate increases at large 
commercial/industrial customers' usage during summer peak periods (e.g., 12-6 PM) and at high-usage residential customers through inverted block rates. Regulators were constrained in their efforts to adjust retail rates by California's original restructuring legislation, legislation passed during the crisis, time lags imposed by regulatory due process requirements, and their own reluctance to pass through volatile and high prices from a "broken" wholesale electricity market onto California consumers (see Section 5).

- The success of long-dormant utility load management (LM) activities was instrumental in preventing blackouts on several occasions during summer 2000. However, these initial successes came at a cost: the LM programs, as originally designed, could not be relied on to provide this capability going into summer 2001. Efforts to develop replacement programs to shore-up the demand response capability were thwarted by the very short time available to put new programs in place and by regulatory reluctance to consider programmatic options that would allow customers to directly experience the real-time price volatility of California's wholesale electricity markets. Ultimately, the capability that was put in place was, fortunately, only called on once. Other customer load reductions were sufficient to preclude having to call on these DR programs more frequently (see Section 6).

- The 20/20 rebate program was a simple, easily understood program that was effective in stimulating load reductions, although its influence is not easily separated from the many other complementary activities that took place in California. We estimated a lower bound cost for savings achieved in the 20/20 program at about $\$ 90 / \mathrm{MWh}$, which compares favorably to supply-side options under consideration when the program was approved. However, if two-thirds of the 20/20 load reductions paid for by utilities were actually attributable to other initiatives (e.g., media campaign, other utility or State programs), then the program's economics are comparable to supply-side options that were expected to be available during this period (e.g., \$260-280/MWh) [see Section 7].

- Utility energy efficiency programs played an important role in providing technical assistance and financial incentives that stimulated customer investments in high-efficiency equipment that reduced electricity demand during summer 2001 and beyond. Building on their longterm relationships with energy efficiency service providers, the utilities were able to ramp up and implement a broad array of program initiatives relatively quickly (see Section 8).

- Various state agencies, with the California Energy Commission assuming a leading role in program administration, implemented a broad array of near- and long-term initiatives to reduce electricity demand in response to State legislation (AB970) that endorsed a "balanced response" to the electricity crisis. Our analysis suggests that longer-term state-led initiatives, such as updating appliance and building energy efficiency standards and financial incentives for distributed energy resources and real-time metering, are likely to yield demand reductions that are comparable to the peak demand impacts of state-led initiatives that focused on nearterm results (see Section 9).

- About $25-30 \%$ of the 4,200 MW of customer load reductions observed in summer 2001 can be attributed to savings from energy efficiency or onsite generation projects, which are likely to persist for many years. About $70-75 \%$ of the observed customer load reductions in 
summer 2001 were due to changes that customers made in their conservation behavior and energy management operations. It is much less clear the extent to which these changes will persist over the long-term, because it depends in part on customer's continuing perception of electricity or other energy crises (e.g., oil embargoes, high gasoline prices or lengthy gas lines) as well as customer's price sensitivity to retail rate trends. The State's current demand response (DR) capability enrolled in utility or CAISO programs is somewhat lower $(\sim 500$ MW) than prior to the crisis, although several long-term state initiatives under CEC auspices have the potential to significantly increase DR capability in the future (see Section 10).

Major lessons for policymakers in other regions include:

- During a short-term crisis, a comprehensive set of load curtailment programs and policies can make a significant contribution towards maintaining electric system reliability. This strategy can be an effective alternative to strategies that rely solely on rationing demand or price increases. California taxpayers and ratepayers invested an additional $\sim \$ 1.3$ billion in 2001 on various energy efficiency, demand response, and on-site generation initiatives. Compared to the estimated economic losses from several hundred hours of predicted rolling blackouts, these demand-side initiatives appear to have been good investments.

- A commitment by policymakers to ratepayer-funded energy efficiency programs and energy efficiency standards for appliances and buildings are critical elements of a long-term strategy to dampen growth in electricity and energy demand. A robust utility energy efficiency program delivery infrastructure, which includes relationships with contractors, vendors, and retailers that leverage key investment decision points within the energy efficiency product and services supply chain, represents a significant resource that can be ramped up to quickly respond to short- and long-term electricity shortages. For example, in California, the dramatic increases in market penetration of energy efficient products in mass markets and accelerated development of complex projects in large customer facilities was undertaken by an energy efficiency services infrastructure that had been nurtured by public policies and funding for over a decade. Thus, ratepayer funding, justified primarily by traditional energy efficiency objectives, or public benefits funds in restructured markets, can help preserve and expand an energy efficiency services infrastructure in order to maintain this capability for response to short-term emergencies.

- California's regulators and utilities essentially mothballed load management programs during the four-year transition period. Utility load management LM programs did provide critical emergency relief during 2000, although the programs were not well suited for the requirements of restructured electricity markets. Thus, it is important to adapt and re-design utility load management programs long before an electricity crisis, so that retail customer loads, working through aggregators, can participate directly in bulk power markets and respond to high prices and/or system contingencies. Doing so is critical to "firming-up" the true capability of these emergency demand response resources, which serve as the last option prior to initiating rolling blackouts. As part of this process, the roles, responsibilities, and coordination issues among load serving entities and new transmission system operators must also be addressed. 
- If regions are facing chronic electricity shortages that are spread over many hours, then a 20/20 type program is worth considering. In terms of program design, we believe this type of program is most appropriate for smaller customers (e.g., residential and small commercial). Among large C/I customers, a combination of voluntary initiatives in government and private sectors, targeted financial incentives for high-efficiency or demand response equipment, and pricing/rate design strategies that reflect wholesale market costs are more likely to achieve load reductions at lower cost than a 20/20 type program. ${ }^{19}$ Setting a high usage reduction threshold (e.g., 20\%) is important because it sends an important signal regarding the need for significant action and may reduce "free riders" compared to a program design with lower reduction thresholds (e.g., 5-10\%). If electricity shortages are projected for only a few hours, then other types of demand-side initiatives may be more appropriate and effective (e.g., voluntary conservation, demand response or energy efficiency programs, pricing).

\footnotetext{
${ }^{19}$ Large customers typically have the necessary metering and communication technologies to respond to more sophisticated pricing tariffs and signals and are often targeted as key participants in existing programs that provide incentives for energy efficiency or "clean" on-site generation. Thus, they have less need for additional incentives that are offered in a $20 / 20$ program.
} 


\section{References}

AUS Consultants. (2001). "Impact of a Continuing Electricity Crisis on the California Economy," Study Prepared for the California Alliance for Energy \& Economic Stability, May 3.

Baldassare, Mark. (1998). "PPIC Statewide Survey: Californians and Their Government," Conducted for the Public Policy Institute of California, December.

. (1999). "PPIC Statewide Survey: Californians and Their Government," Conducted for the Public Policy Institute of California, December.

. (2001a). "PPIC Statewide Survey: Californians and Their Government," Conducted for the Public Policy Institute of California, January.

. (2001b). "PPIC Statewide Survey: Californians and Their Government," Conducted for the Public Policy Institute of California, July.

(2001c). "PPIC Statewide Survey: Californians and Their Government," Conducted for the Public Policy Institute of California, December.

Bay Area Economic Forum. (2001). "The Bay Area - A Knowledge Economy Needs Power," April.

Bell, Andrew (2002). Private correspondence, January 4, 2002.

Borenstein, Severin. (2001). "The Trouble with Electricity Markets (and some solutions)." University of California Energy Institute, Program on Workable Energy Regulation (POWER), PWP-81. January.

Chan, Terry. (2001). "20/20 Vision: California's Cash for Conservation Strategy, "Association of Energy Services Professional International Strategies, Fall 2001.

CAISO. (2001a). "System Status Log," http://www.caiso.com/docs/2001/06/01/200106011228581047.html.

. (2001b). “Operations Economic Report 2001,” issued December 21.

CEC. (2001a). "Actual Data Jan. - Dec. 2001," available for download at www.energy.ca.gov/electricity/peak_demand/2001_peak_demand.html.

. (2001b). "Proposals of the California Energy Commission for Modified Demand Reduction Programs," Filed with the California Public Utilities Commission under Proceedings for R. 00-10-002, November 9.

. (2001c). "Database of Public Back-Up Generators (BUGS) in California," http://www.energy.ca.gov/database/index.html\#bugs. 
. (2002a). "Proposed Negative Declaration AB970 Energy Efficiency Standards for Appliances," January 9.

. (2002b). "The Summer 2001 Conservation Report," www.energy.ca.gov.

CPUC. (2001a). California Public Utilities Commission (CPUC) Decision 01-05-064, Issued May 15, 2001.

. (2001b). "Energy Division's Report on Interruptible Programs and Rotating Outages." Filed with the California Public Utilities Commission under Proceedings for R. 0010-002, February 8.

. (2001c). California Public Utilities Commission (CPUC) Decision 01-01-060, Issued January 30, 2001.

. (2001d). "CPUC 2001 Energy Efficiency and Conservation Programs Report to the Legislature," December.

. (2002). "CPUC Self-Generation Incentive Program July - December 2001 Status

Report,” http://www.cpuc.ca.gov/PUBLISHED/REPORT/13690.htm.

DOF. (2001). "California Employment Data," California Department of Finance, http://www.dof.ca.gov/HTML/FS_DATA/LatestEconData/FS_Employment.htm.

DWR. (2001a). "Determination of Revenue Requirements," Submitted to the California Public Utilities Commission, November 5, 2001.

. (2001b). "Update of California Department of Water Resources Power Purchase Contract Efforts," May 31.

E Source. (2002). "California Energy Efficiency in 2001: Customer Actions and Perceptions," January.

Eto, J., Goldman, C., and Nadel, S. (1998). "Ratepayer-Funded Energy-Efficiency Programs in a Restructured Electricity Industry: Issues and Options for Regulators and Legislators," LBNL41479.

Goldman, Charles, Eto, Joe, and Barbose, Galen. (2002). "California Customer Load Reductions during the Electricity Crisis: Did They Help To Keep the Lights On?” LBNL-49733.

Jaske, Michael and A. H. Rosenfeld (2001). "Developing Demand Responsiveness in California's Energy Markets," Western Economics Association $76^{\text {th }}$ Annual Conference, July. 
Lutzenhiser, Loren. (2001). "An Exploratory Analysis of Residential Electricity Conservation Survey and Billing Data: Southern California Edison, Summer 2001," prepared for the California Energy Commission, December 6.

McNary, Bill. (2002). Personal communication, April 9.

Miller, Sandy. (2002). Manager of CEC Emerging Renewable Buydown Program, Personal communication, April 3.

NCDC. (2002). "California Climate Summary March 2002,” National Climatic Data Center, National Oceanic and Atmospheric Administration, http://lwf.ncdc.noaa.gov/oa/climate/research/cag3/CA.html.

NERC. (2001). “2001 Summer Special Assessment,” North American Electric Reliability Council, May.

Nexant. (2001). “AB970, AB29X and SB5X Peak Load Reduction Programs." Prepared for California Energy Commission and the California State Legislature, December 10.

Nittler, Ken. (2002). Personal communication, April 11.

OER. (2002). "Latest CA GSP and World Ranking," Office of Economic Research, California Technology, Trade, and Commerce Agency, http://134.186.44.154/ersi/oer/GSP.html.

Office of the Governor. (2001a). Proclamation by the Governor of the State of California, January 17.

. (2001b). "Executive Order D-30-01," Issued March 14, 2001.

. (2001c). "Governor Announces State Buildings Curb Energy Use by Nearly 23 Percent in 2001." Press Release Issued August 14, 2001.

. (2001d). "Local Governments Join Governor Davis in Commitment to Energy Conservation.” Press Release Issued April 30, 2001.

OPT. (2001). "Barrier, Opportunities, and Options Related to Backup and Portable Energy Generation During an Energy Emergency in California,” Energy Emergency Task Force, Office of Power Technologies, Office of Energy Efficiency and Renewable Energy, May 25.

ORA. (2002). Website for the California Office of Ratepayer Advocates, http://www.ora.ca.gov/selfgen.htm.

Pang, Terry (2001). "The 'Amazing' California CFL Story." Presentation at the ACEEE National Conference on Energy Efficiency and Reliability, October 29 and 30, 2001. 
PG\&E. (2001a). "Californians Purchase Record Number of Energy Efficient Products in 2001." Press Release Issued November 29, 2001.

. (2001b). "Pacific Gas and Electric Company Quarterly Program and Expenditures Report to the Energy Division: April 1, 2001 through June 30, 2001," August.

. (2001c). "Pacific Gas and Electric Company Quarterly Program and Expenditures Report to the Energy Division: July 1, 2001 through September 30, 2001," November.

. (2001d). "Pacific Gas and Electric Company's Monthly Report on Interruptible and Outage Programs," Filed with the California Public Utilities Commission under Proceedings for R. 00-10-002, October 8 .

. (2002a). "Pacific Gas and Electric Company Quarterly Program and Expenditures Report to the Energy Division: October 1, 2001 through December 31, 2001," February.

. (2002b). "Report of Pacific Gas and Electric Company on Interruptible and Outage Programs," Filed with the California Public Utilities Commission under Proceedings for R. 0010-002, March 7.

Quantum Consulting. (2001). "Statewide Small/Medium Nonresidential Customer Needs and Wants Study," Prepared for Chris Ann Dickerson, Pacific Gas and Electric Co., December.

Rufo, Mike. (2002). Personal communication, April 22.

SCE. (2001a). "SCE Responds to CPUC Decision Broadening Number of Energy-Efficiency Program Providers." Press Release Issued November 29, 2001.

. (2001b). "Southern California Edison 2001 Energy Efficiency Programs Second Quarter Report," August 15.

. (2001c). "Southern California Edison 2001 Energy Efficiency Programs Third Quarter Report," November 15.

. (2001d). "Monthly Report of Southern California Edison Company (U 338-E) on Interruptible and Outage Programs," Filed with the California Public Utilities Commission under Proceedings for R. 00-10-002, October 9.

. (2002a). "Southern California Edison 2001 Energy Efficiency Programs Fourth Quarter Report,” February 15.

. (2002b). "Monthly Report of Southern California Edison Company (U 338-E) on Interruptible and Outage Programs," Filed with the California Public Utilities Commission under Proceedings for R. 00-10-002, March 7. 
SDG\&E. (2001a). "San Diego Gas \& Electric PY2001 Energy Efficiency Programs Second Quarter Report," August 14.

. (2001b). "San Diego Gas \& Electric PY2001 Energy Efficiency Programs Third Quarter Report," November 14.

. (2001c). "San Diego Gas \& Electric Company's September 2001 Report on Interruptible and Outage Programs," Filed with the California Public Utilities Commission under Proceedings for R. 00-10-002, October 9.

. (2002). "San Diego Gas \& Electric Company's February 2002 Report on

Interruptible and Outage Programs," Filed with the California Public Utilities Commission under Proceedings for R. 00-10-002, March 7.

Wallenrod, Mark (2001). "SCE Load Reduction Programs - Post Summer 2001 Update." Presentation at CEC Demand Response Workshop, September 27, 2001. 